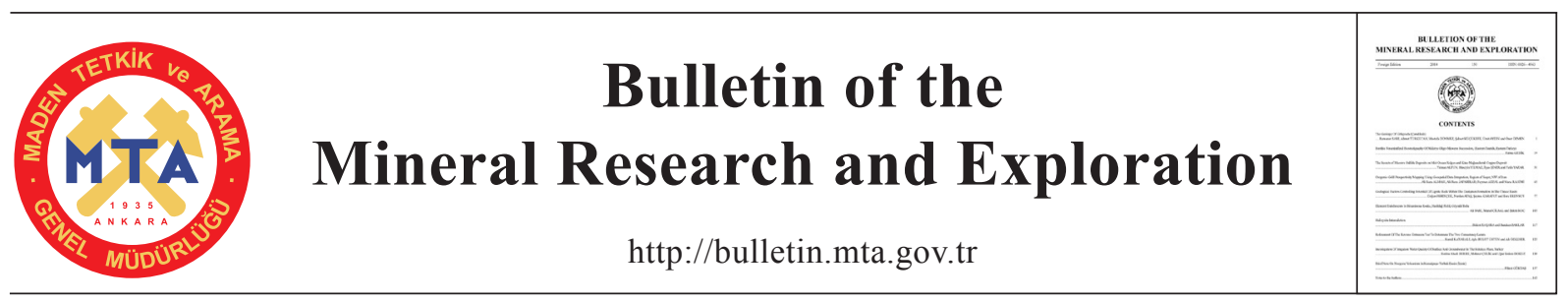

\title{
GEOLOGICAL FACTORS CONTROLLING POTENTIAL OF LIGNITE BEDS WITHIN THE DANIŞMEN FORMATION IN THE THRACE BASIN
}

\author{
Doğan PERINÇEK ${ }^{a^{*}}$, Nurdan ATAŞ ${ }^{a}$, Şeyma KARATUTT and Esra ERENSOYa \\ ${ }^{a}$ Çanakkale Onsekiz Mart Üniversitesi, Mühendislik Fakültesi, Jeoloji Mühendisliği Bölümü, Çanakkale
}

Keywords:

Thrace Basin, Lignite,

Thrace Fault System

\begin{abstract}
This project has been conducted for the General Directorate of Turkish Coal Enterprise. The aim of this study is to understand lignite potential of the basin. Subsurface data (including numerous wells and several seismic lines) provided by TPAO, MTA and TKİ were used. Structure and thickness maps of Oligocene-Miocene-Pliocene units prepared for the basin. Purpose of this work is to understand economical values of lignite seam beds interbedding in the Danişmen Formation (Oligocene-Early Miocene). For this purpose, from bottom to top following maps were prepared: Structural map of the top Osmanc1k (Oligocene) Formation, thickness map of the Danişmen Formation, paleo-topographic map of unconformity surface which is at the top of the Danişmen Formation, total thickness map of Ergene-Kırcasalih formations (Late Miocene-Pliocene). Finally total thickness map of the lignite layers was prepared. It was the main purpose of the work. Lignite seam layers are located in middle of the Danişmen Formation. Also several stratigraphic correlations were conducted to understand lateral continuation of lignite layers. The first obstacle to reach lignite is thickness of the Ergene and Kırcasalih formations which overlie lignite bearing Danişmen Formation. Main structural event controlling the thickness variation of the Danişmen Formation is Thrace Fault System (Perinçek, 1991); it was active during Middle Miocene. Danişmen Formation extensively or partially was eroded along the fault zone and on the en-echelon folds of the fault system. Amount of erosion is variable and in some areas Danişmen Formation completely was eroded. As a result Ergene Formation lies directly on Osmanc1k Formation. Lignite layers are also eroded at these localities. Elevated areas related the Thrace Fault System partially was eroded; however these areas were still paleo-elevated areas during the accumulation of Ergene Formation. Onlapping sequence of Ergene Formation is thinner on these areas. At the end of this project, thicker lignite areas were delineated. Addition to this, thin overburden areas on lignite are located. Considering these results, new permit areas were selected. In order to refine this work, a suggested facies map of Danişmen Formation is advise to be prepared.
\end{abstract}

\section{Introduction}

According to the agreement between Çanakkale Onsekiz Mart University and Turkish Coal Enterprise (TKI) lignite potential of Thrace Basin was investigated. The project which lasted 1.5 years was started in mid 2009 and ended in December 2010. Underground geology data set necessary for the implementation of this project was provided by TKI, TPAO and MTA. The data set includes shallow and deep well data, seismic sections and core samples from some wells. Permission to access the data was taken from TKI at the beginning of study.

In the second half of the project, in order to reliably determine the locations of the wells to be drilled in the license area, seismic lines of Turkish Petroleum Corporation (TPAO) that were provided by TKİ were evaluated. Total lignite thickness map was compared to other thickness and structure maps that were produced in the first stage of project and thus data synergy and consistency were maintained 
and considering seismic assessment new license areas were proposed in the Thrace basin.

The Thrace basin is surrounded by Istranca at north, Rhodope at west and Menderes massif to the south. The Istranca massif is represented by gneissic rocks at the bottom and overlying Paleozoic and Mesozoic sedimentary rocks that were metamorphosed in greenschist facies (Üşümezsoy, 1982; Taner and Çağatay, 1983). The sedimentary rocks are cut by Late Cretaceous granodioritic rocks and locally covered by a volcano-sedimentary unit (Taner and Çağatay, 1983). Granitic rocks are exposed at southern flank of the Istranca massif (Öztunalı and Üşümezsoy 1979).

Intense geological research has been carried out in the Thrace basin to exploit oil and gas potential of the region. Studies of Kopp et al. (1969), Turgut et al. (1983, 1991), Saner (1985) and Siyako (2006 a, b) discuss the geology of basin. Geology maps prepared by the General Directorate of Mineral Research and Exploration are the most important sources for stratigraphical nomenclature of the Thrace basin (İmik, 1988; Umut, 1988a, Çağlayan and Yurtsever, 1998, Şentürk et al., $1998 a, b$ ).

In central and northern Thrace, Miocene and postMiocene units cover the Eocene-Oligocene sequence. Therefore, lithostratigraphic framework of the Thrace basin is established based on information from rock units exposing in southern Thrace, Gallipoli Peninsula,
Bozcaada and Gökçeada and also seismic lines oil exploration wells. Eocene-Oligocene sequences of the Thrace basin crop out at south of the Sea of Marmara and Biga Peninsula (Siyako et al., 1989), in the area between Mudanya and Tirilye and Armutlu Peninsula (Akartuna, 1968) and therefore the southern border of the basin is not definite (Siyako, 2006 b).

The Thrace basin is a triangular shaped intermountain Tertiary basin in which Middle EocenePliocene units are exposed (Keskin, 1974). In the basin sedimentation was probably started in the Early Eocene with a transgressive sequence (Keskin, 1974, Doust and Arıkan, 1974, Turgut et al., 1983, Saner, 1985). Ignoring discontinuities and erosion, sedimentation as continued until very recently. The basement of basin is comprised by a metamorphic complex. The Tertiary sequence that almost comprises the whole Thrace region exposing from southern flanks of the Istranca Mountains (Figure 1) has a thickness of more than 9000 m (Kopp et al., 1969; Turgut et al., 1983; Turgut et al., 1991; Perinçek, 1987; Görür and Okay, 1996; Turgut and Eseller, 2000; Siyako, 2005; $2006 a ; 2006 b)$. Tertiary units in Thrace are composed mostly of clastics but contain carbonates in shelf areas and ridges and hills in the central basin. These units were deposited in seven different time intervals in basins characterized by significant uplift and erosion stages (Figures 1 and 2). In central parts of the basin, sedimentation is partly continuous whilst some parts come up with discontinuity and erosion stages. The

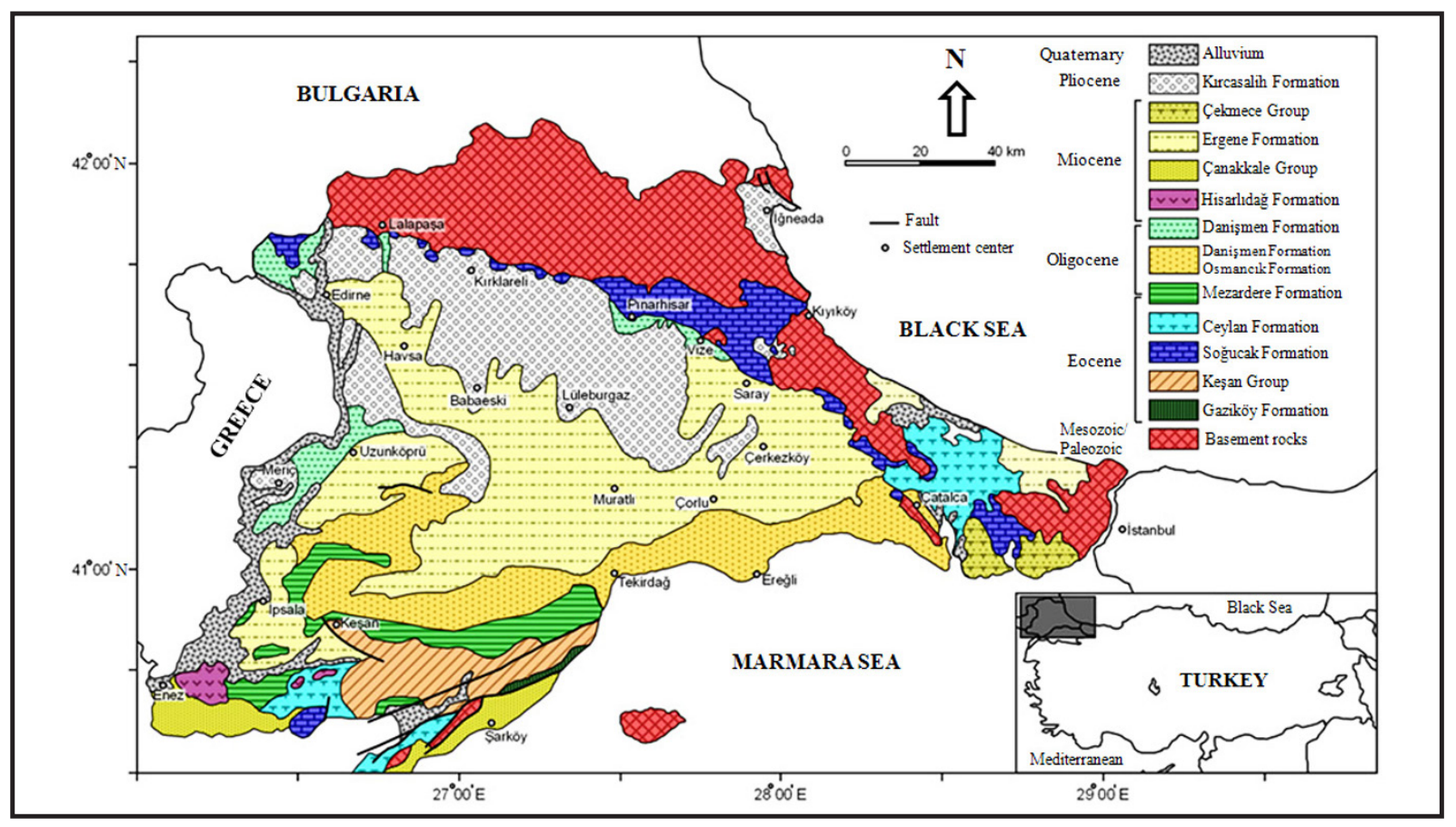

Figure 1- Geology map of Thrace basin (Kasar et al., 1983; Türkecan and Yurtsever, 2002; Siyako, 2006b). 


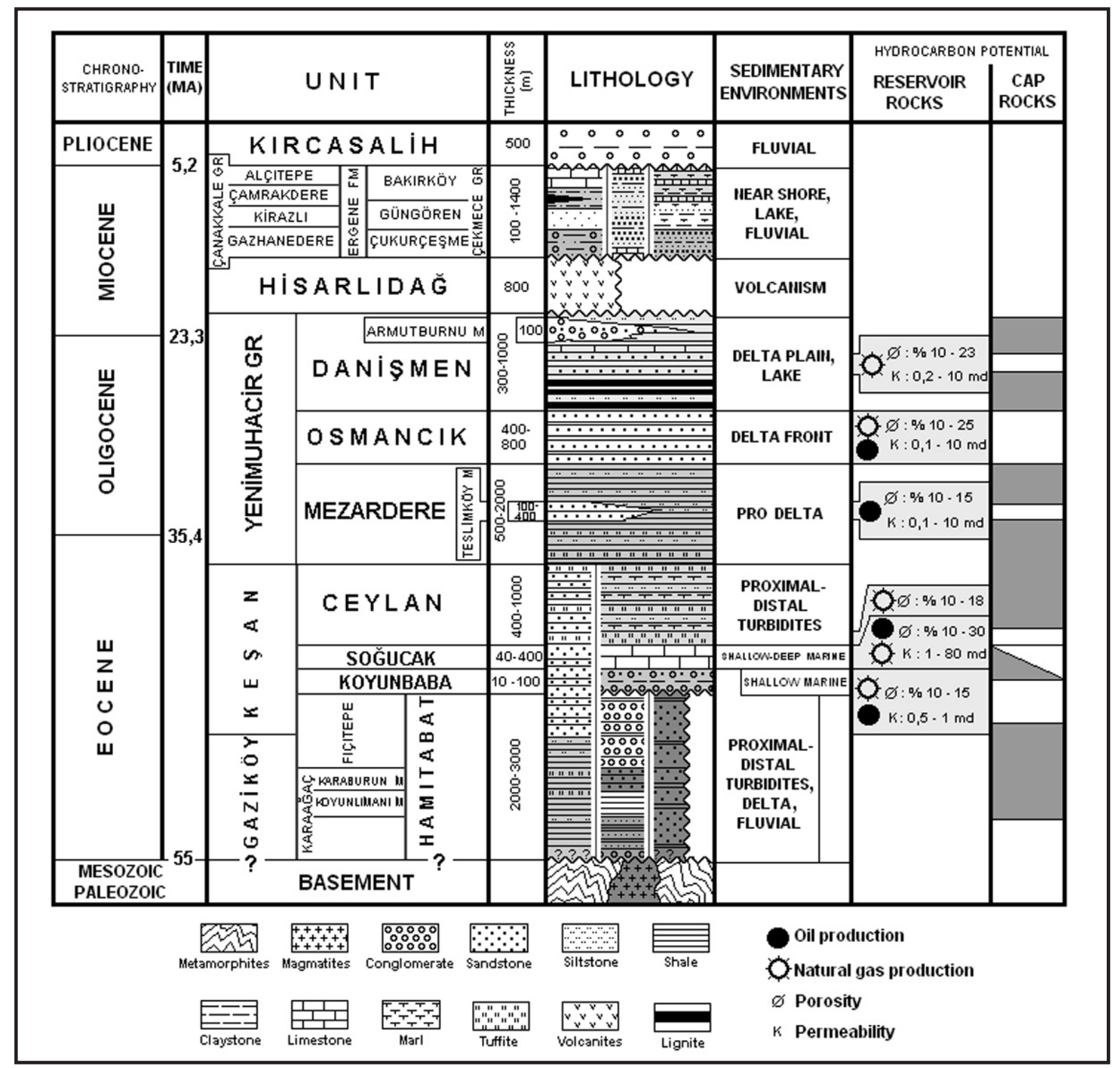

Figure 2- Generalized stratigraphic section of the Tertiary sequence in the Thrace basin (Siyako 2006a).

basin is a fast-depositing type and has a syntectonic character. As revealed from several seismic lines, the sequence which at the beginning filled pits of an irregular topography has transgressive onlaps above the basement toward the land (Burke and Uğurtaş, 1974; Perinçek, 1987).

The Eocene transgression attained maxima in the Early Oligocene. In the Middle Eocene-Early Oligocene, deep parts of the basin were filled by turbiditic currents that were carried by density flows whilst carbonates were deposited in shelf and Kuleli - Babaeski paleo-height at the north (Turgut et al., 1983; Keskin, 1974). In the meantime, the Thrace basin was controlled by a deltaic system of a large river and submarine fans were formed (Turgut et al., 1983). In the Late Eocene-Early Oligocene aged dacitic and andesitic ashes formed interlayers within the sediments (Doust and Arıkan, 1974; Turgut et al., 1983). Eocene transgression was followed by Middle Oligocene-Lower Miocene regression (Keskin, 1974; Ediger, 1982; 1988; Turgut et al., 1983; Saner, 1985). After a pause in sedimentation during the Middle Miocene, terrestrial palinofasies of the Ergene and Kurcasalih formations of Late Miocene ? - Early Pliocene age were deposited (Ediger, 1982). The pause in sedimentation was in the Middle Miocene and Late Miocene, Early Pliocene-Pleistocene aged fine grained terrestrial unit was the first product of new deposition period. There was also a less significant unconformity between Late Miocene and Pliocene. 
Due to its lignite potential the basin has been the subject of intense geologic research (e.g. Lebküchner, 1974; Kara et al., 1996; Şengüler et al., 2000; Şengüler et al., 2003; Sütçü et al., 2009, Şengüler, 2008, 2013). Lignite fields in north of Thrace basin are generally found on flanks of the Istranca massif-İstanbul-SilivriSinekli; Tekirdağ-Saray-Küçük Yoncalı; Tekirdağ Saray - Safaalan; Tekirdağ - Saray - Edirköy fields. Coal occurrences in south of the Thrace basin include Keşan, Malkara, Uzunköprü and Meriç fields. Lignites at north and south of the basin gradually deepen to the center of basin and attain a depth of $600 \mathrm{~m}$ within the $10.000 \mathrm{~m}$-thickened sequence (Şengüler, 2013). Lebküchner (1974) studied regional geology and fossil assemblage and chronology of the formation so called ligniferous sandstone. Kara et al. (1996) studied general geology of the basin and provided information on important coal fields in the Thrace basin. Şengüler et al. (2000) studied coal samples collected from Keşan, Malkara and Uzunköprü coal fields. In these studies, they particularly investigated the operated veins and evaluated the deposition environment of coal. In a report prepared as 2 volumes by Şengüler (2008), distribution, properties and deposition model of Thrace coals and known field and enterprises are explained. Thrace basin coals were deposited in delta swamps of lacustrine environments. High deposition rate resulted in deposit thickness to be high which complicated the correlation of coal veins (Şengüler, 2013). During the formation of Danişmen Formation fluvial conditions were effective which hampered lignite deposition.

The North Anatolian Fault Zone (NAFZ), which is one of the important structural components comprising the general tectonic frame of Anatolia and Balkans has been active since Miocene and studied in detail by several earth scientists (Ketin, 1957; Fourquin, 1979; Barka, 1981; Barka and Hancock, 1984). The North Anatolian Fault Zone extends along the Cretaceous suture belt or cuts this belt a few times. The Thrace fault system which is the oldest branch of NAFZ in Thrace shows similar features to NAFZ. The Thrace fault system is composed of three fault members (Perinçek, 1987; 1991). The structural lines forming this fault system extends from Silivri to Edirne through the basin (Figure 1). The aim of this work is to 1) to determine the geometry of fault system, 2) evaluate the tectonic interrelations and origin, 3) to determine its age and 4) discuss slip rate of Thrace fault system. With the exception of last item, Perinçek $(1987,1991)$ has accomplished the objectives of all others.
Within the scope of project, following studies were implemented which are summarized below. These studies are composed of regional maps that are required to determine the lignite potential of Thrace basin. Information obtained by the virtue of these maps is useful not only for TKİ but also for TPAO and MTA. Results from this project are intended to contribute to studies of all relevant governmental organizations

As a result these studies, the maps produced are Osmanckk Formation structure map, Danişmen Formation discordance plane paleo-topography map, thickness map for Danişmen and Ergene Formations and total thickness map of lignite levels within the Danişmen Formation. The reason for construction of thickness and structure maps mentioned above is to determine the economic depth of lignite levels and the areas where lignite has the maximum thickness. One of the obstacles encountered in lignite explorations in Thrace basin is that lignite occurs at a considerable depth under a thick cover.

In addition to maps, another important study is the correlations among the wells. These might significantly contribute to determining the lateral facies changes of Danişmen Formation and lateral thickness change of lignite layers. It is possible to see the vertical and horizontal facies changes in correlations. Even different lithology descriptions were made by different geologists in wells that are opened in close distances by TKİ and MTA which complicated the correlation. Therefore, it took a long time for data coupling.

Lignite exploration in Thrace was carried out in northeastern and south of basin where lignite levels are widely exposed. Using the outcomes of this study that was conducted for TKI a new exploration strategy was established. In this respect, new licenses are proposed for paleo-heights of the Thrace Fault System. The areas where the Danişmen Formation exposing around the paleo-height areas were partly eroded and where the overlying Ergene Formation is thinner are selected as target areas. This new strategy is one of the most important results of present study and no other exploration study was conducted using the proposed approach.

\section{Stratigraphy}

The simplified geology map and generalized stratigraphic columnar section of the Thrace basin are given figures 1 and 2, respectively. The relations of 
Danişmen Formation to Osmancık Formation and to its members are shown in figure 3.

In the Thrace basin Paleocene-Pleistocene deposits are separated from each other with an angular unconformity (Siyako, 2006b). Paleocene-Lower Eocene deposits are exposed in a limited area in southwest Thrace and Gallipoli Peninsula and overlain by Middle Eocene limestone (Siyako, 2006a, $b$ ).

Early-Middle Eocene aged various terrestrial and marine units are in vertical and lateral transition (Figure 3) (Siyako, 2005; 2006a). In the Late Eocene Keşan Formation and overlying Ceylan Formation were deposited and both units, although there are some lithological differences, are composed of marine turbidites. Getting shallow depth of environment during Late Eocene-Early Oligocene the sequence so called Yenimuhacir Group (Figure 3) was deposited (Kasar et al., 1983; Saner, 1985; Sümengen and Terlemez, 1991; Atalık, 1992; Siyako, 2005, 2006b). In association with this system, the Mezardere, Osmancık and Danişmen formations were deposited until Early Miocene (Ünal, 1967; Kasar et al., 1983; Siyako, 2005; 2006b). At the end of this stage, the region was completely filled and uplifted and became a land and following an erosion stage deposition of Late Miocene-Pliocene units was started.

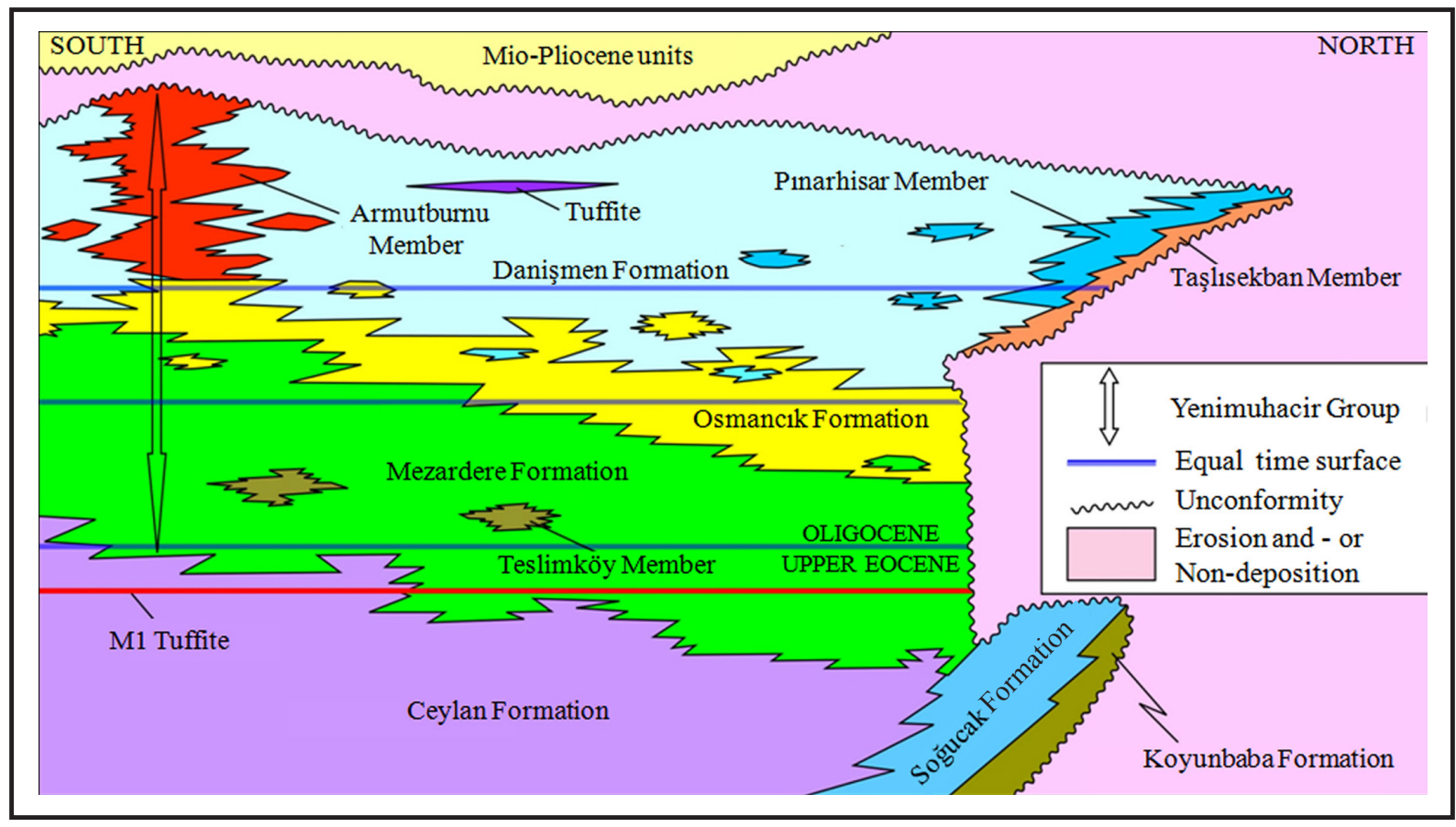

Figure 3- Correlation of Ceylan Formation and Yenimuhacir Group units. Taşlisekban, Pınarhisar and Armutburnu members were differentiated from bottom to top within the Danişmen formation (Siyako, 2006b).

During the Early-Middle Miocene, the volcanics of Hisarlıdağ formation with scarce sediment interlayers were formed in southwestern Thrace.

The Upper Miocene units are known as Çanakkale and Çekmece groups and Ergene Formation (Siyako, 2006b). The Karatepe Basalt is also of Miocene age. Pliocene is represented by the Kurcasalih Formation which is widely exposed particularly in northern Thrace (Siyako, 2006b). The Pleistocene units are investigated as Marmara Formation which is composed of marine terrace deposits around the Sea of Marmara.

\subsection{Yenimuhacir Group}

The name of Yenimuhacir was first used as a formation name. Later, Ünal (1967) studied the unit as a group in which four different formations were differentiated. In first studies conducted in the region the unit which was referred as "ligniferous sandstones" represents delta front and delta flat environments of the Yenimuhacir group (Siyako, 2006b). The Yenimuhacir group, from bottom to top, is composed of Mezardere, Osmancık and Danişmen formations (Figures 1 and 3). In its type section the thickness of Mezardere formation is $1540 \mathrm{~m}$ (Kasar et al., 1983). According to palynological studies, the age of formation is Late 
Eocene-Early Oligocene which may be up to Late Oligocene within the basin fill (Ediger and Alişan, 1989; Bat1 et al., 1993; Bat1 et al., 2002).

The unit gradually passes to underlying Ceylan and Keşan formations. In paleohighs where underlying Ceylan formation is absent it is transitional to Soğucak Formation. In areas where Mezardere and Osmancık formations are absent, the Yenimuhacir group unconformably overlies the older lithologies (Figure 3). The unit is eroded and unconformably overlain by young units.

Formations comprising the Yenimuhacir group are formed in delta front, delta plain and prodelta of a classical delta system and interfinger to each other in lateral and vertical directions and therefore should be mapped separately. The Yenimuhacir group is composed of clastic rocks such as shale, siltstone, sandstone and conglomerate lithologies with coarser grain-size to the top. These clastics contain tuff, limestone and lignite interlayers. Tuffs can be differentiated as marker and traced in a long distance. Sandstone levels are also found within the unit and they can be mapped separately as the Teslimköy member (Figures 2 and 3) (Kasar et al., 1983).

Total thickness of the Yenimuhacir group is 3500 $\mathrm{m}$. Based on palynomorph assemblage, it is of Late Eocene-Early Miocene age (Alişan, 1985; Gerhard and Alişan, 1987; Ediger and Alişan, 1989; Batı et al., 1993; Bat1 et al., 2002).

2.2. Stratigraphy of units below and above the Danişmen Formation

\subsubsection{Osmanclk Formation}

The Osmancik formation is generally transitional to underlying Mezardere and overlying Danişmen formations. In many parts of the region the Osmancık and overlying Danişmen formations are unconformably overlain by Ergene and Kurcasalih formations. The Osmanck formation is a regressive unit that was deposited in a prograding delta front environment with grain size distribution getting coarser to the top. It is mostly composed of sandstone, shale and less amount of conglomerate, limestone and tuff levels. In the type section the Osmancik formation has a thickness of $810 \mathrm{~m}$. Similar thicknesses were also observed in wells drilled in the Thrace region (Temel and Çiftçi, 2002). In palynological studies conducted on Osmancık formation yielded terrestrial and marine palynomorphs of Early-Late Oligocene age (Ediger and Alişan, 1989; Bat1 et al., 1993; Bat1 et al., 2002; Siyako, 2006b).

\subsubsection{Danişmen Formation}

Danişmen shale was first described in formation stage by Ünal (1967). Kasar et al. (1983) changed the name to Danişmen Formation since the lithology is not homogeneous. Taşlisekban and Pınarhisar members were differentiated at the base of unit whilst Armutburnu member occurs in lateral and vertical transition. The Danişmen Formation gradually changes to underlying Osmancik formation. In some areas the Danişmen Formation is significantly eroded and unconformably overlain by young units. The unit unconformably sets above the older units on the flanks of Istranca where Osmancik and Mezardere formations are absent. The Danişmen Formation is the upmost unit of regressive delta system and represents for delta flat facies. It is composed of lacustrine, swamp, flood plain and fluvial deposits. The unit consists of claystone, sandstone, conglomerate and coal layers (Figure 4). Fish fossils on exposures in northern Thrace and silicified woods in southern Thrace are very common. Tuff-tuffite and limestone levels are rarely observed. The underground thickness of Danişmen Formation is nearly $1000 \mathrm{~m}$. Since units is eroded from the top, its original thickness might be more than that (Siyako, 2005; 2006b). Thickness decreases to the margins of basin. The unit was aged as Late Oligocene by Kasar and Eren (1986) and Batı et al. (2002) and Early Oligocene by Saraç (1987). In some other works it is suggested to be Late OligoceneEarly Miocene in age (Alişan, 1985; Gerhard and Alişan, 1987; Bat1 et al., 1993). Vertebrate faunas are very common in lignite veins of the Danişmen Formation. According to descriptions on vertebrate fossil, the age of formation corresponds to Middle Oligocene (Umut et al., 1983; 1984).

The base of lignite levels in lower part of the Danişmen Formation observed in drilling works is explained as the contact between Danişmen and Osmanc1k Formations (Siyako, 2005; 2006b). In unpublished geology maps of TPAO that cover only a small area, Osmancık and Danişmen formations were partly differentiated on lignite-bearing sandstones (Bürkan, 1992).

Taşlısekban, Pınarhisar and Aramutburnu members were differentiated within the Danişmen formation. In areas where Danişmen formation is exposed lignite layers in this formation are exploited as open and underground pits. 


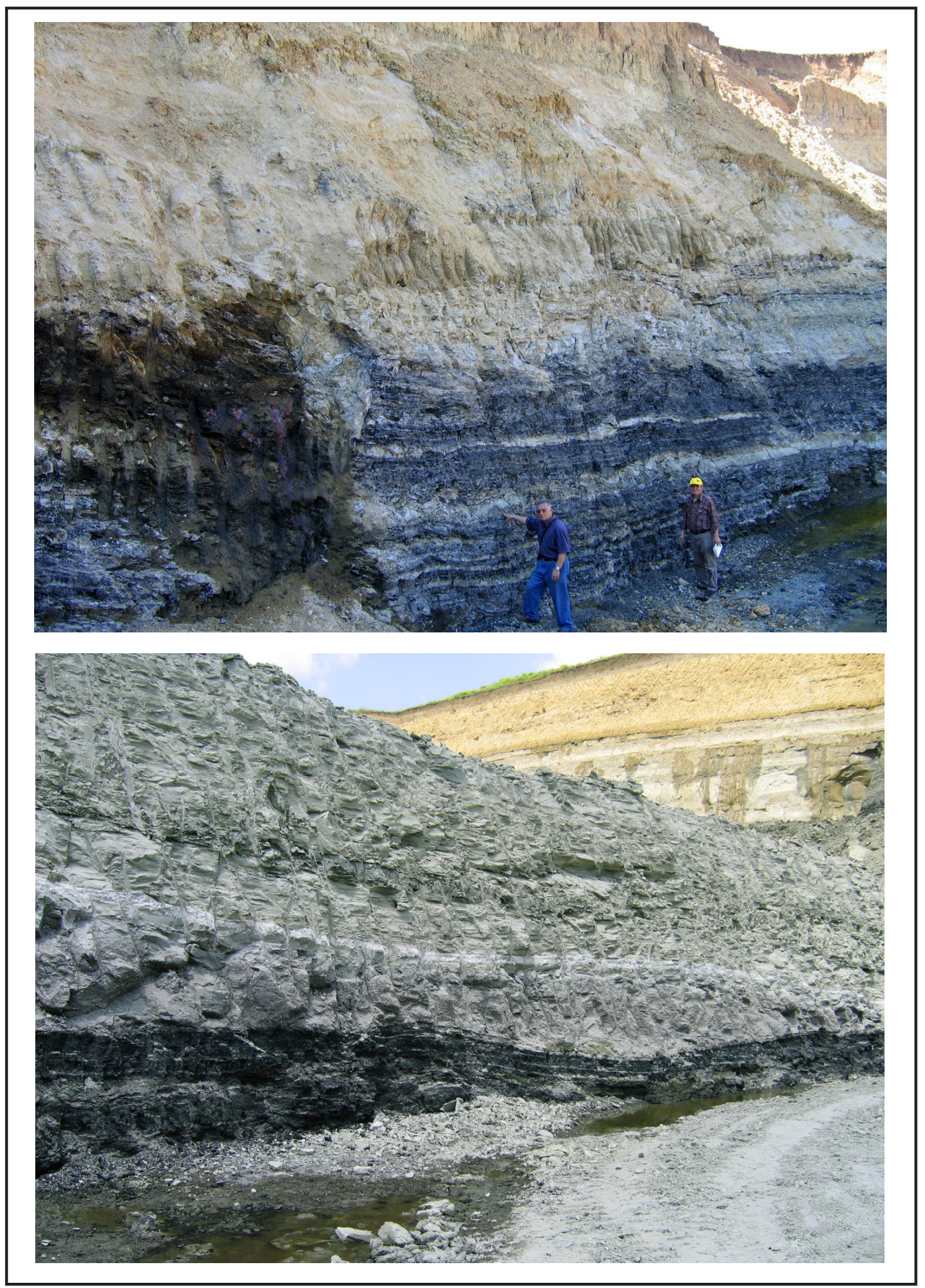

Figure $4 \mathrm{a}$ and b- Lignite layers within the Danişmen Formation are alternated with marls and locally covered with sandstone layers. 
Taşlisekban Member: The unit was first named by Kasar (1987). The unit unconformably overlies the older units. It is transitional to overlying Pınarhisar member. The Taşlısekban member is composed of conglomerate, sandstone and marl. Claystone and lamellibranchia agglomerations are rare. Exposures in Çatalca start with a coarse grained slope wash facies derived from the basement and Soğucak Formation (Çağlayan and Yurtsever, 1998). The Taşlısekban member comprises the basal conglomerates of Pinarhisar member limestones. Thickness of Taşlısekban member is maximum $30 \mathrm{~m}$. According to its stratigraphic setting the age of unit might be Oligocene.

Pinarhisar Member: It is gradually transitional to Taşlisekban member at the bottom and claystone and shale levels of the Danişmen formation to the top. The Pinarhisar member is represented by partly clayey shallow-marine, lagoon limestones with manganeferous levels at the upper parts (Siyako and Kasar, 1985). Limestones also contain sandstone and conglomerate interlayers together with oolite, abundant lamellibranches, gastropod and ostracode. In the type section, thickness was measured as $70-80 \mathrm{~m}$ and average thickness ranges from 5 to $20 \mathrm{~m}$. The age of unit is reported as Early Oligocene (Gökçen, 1971; Kasar and Eren, 1986) and Oligocene (Umut et al., 1983; 1984).

Armutburnu Member: On its type section, the Armutburnu member is in lateral and vertical transition to both Osmanckk and Danişmen Formations (Figure 3). It is overlain by young deposits with an angular unconformity. The member is represented by red colored, thick bedded-massif channel fill conglomerate and sandstone that were deposited in a delta flat. It is composed rarely of flood plain mudstone and sparsely of coal levels. Its thickness is about $100 \mathrm{~m}$ (Temel and Çiftçi, 2002). The age of Armutburnu member is reported as Late Oligocene in Gallipoli (Temel and Çiftçi, 2002) and Oligocene in western Thrace (Umut et al., 1984). Considering the Miocene age suggested by N.V.Turkse Shell (1969), Oligo-Miocene age is accepted for the unit (Siyako, 2006b).

\subsubsection{Ergene Formation}

Miocene deposits at north of Ganosdağ-KorudağHisarlıdağ paleo-height are included to Ergene Formation. Çelebi and Sinanlı members were differentiated within the unit. Kasar et al. (1983), Turgut et al. (1983) and Perinçek (1991) examined the Ergene and Kircasalih Formations under Ergene Group.

The unit is unconformable with older units and overlying Kurcasalih Formation. The unit is composed of cross bedded conglomerates and sandstones of fluvial and lacustrine environment and sandstone and claystone lithologies with abundant plant and vertebrate fossils (Duman et al., 2004; Siyako, 2006b). Thickness of formation is $0-60 \mathrm{~m}$ in basin margins and $800-1200 \mathrm{~m}$ at the center of basin (Siyako, 2006b; Perinçek 2010a, $b$, c). According to Perinçek (1987) the Ergene Group (together with Ergene and Kurcasalih Formations) is of Late Miocene-Pliocene age. The age of Ergene Formation is given as Middle-Late Miocene by Umut et al. (1983), Çağlayan and Yurtsever (1998) and Duman et al. (2004) and Late Miocene by Umut (1988b) and İmik (1988). The unit is exposed in a large area in central part of Thrace.

Çelebi Member: The Çelebi member has an angular unconformity with Armutburnu member of underlying Danişmen Formation (Umut et al., 1984). The clastics of Çelebi member comprising the basement of Ergene Formation are in vertical and lateral transition to this formation (İmik, 1988). At south of Uzunköprü the unit is composed of white, gray, greenish lacustrine limestones. Horizontal, thin-medium bedded limestone layers are interbedded with rare clay and sandstone (Umut et al., 1984; Umut, 1988a; İmik, 1988). Thickness of unit is about $40 \mathrm{~m}$. The age of Çelebi member is accepted Middle-Late Miocene like Ergene Formation which is in vertical and lateral transition to this member (Siyako, 2006b).

Sinanl Member: The unit conformably covers the Ergene Formation and is also in lateral transition to this formation. It is unconformably overlain by Kircasalih Formation (Umut et al., 1983). The Sinanlı member was deposited in a fluvial-lacustrine environment. It starts with nodular limestone level and continues to the top with massive, partly clayey sandstone and claystone interlayered limestone level (Umut et al., 1983; Çağlayan and Yurtsever, 1998). Thickness of Sinanlı member is 10-40 m. The age of Sinanlı member is Middle-Late Miocene like Ergene Formation which is in vertical and lateral transition to this member. 


\subsubsection{Karatepe Basalt}

It was first named as a formation by Umut et al. (1983). It is found in lower levels of the Ergene Formation and within the clastics of the Ergene Formation (Siyako, 2006b). The Karatepe Basalt is composed of black olivine basalts. Basalts are generally as lava flow and show columnar structure. According to Siyako (2006b) they are Late Miocene in age. Volcanic activity of Karatepe Basalt is suggested to be associated with Thrace Fault System (Perinçek 2010b, c).

\subsubsection{Kircasalih (Thrace) Formation}

The name of Kircasalih Formation was first used by Ünal (1967). Umut et al. (1984), Umut (1988a, b), İmik (1988) and Çağlayan and Yurtsever (1998) described the unit as Thrace Formation.

The Kurcasalih Formation unconformably sets above almost all older units in Thrace (İmik, 1988; Siyako 2006b). It is overlain by Quaternary deposits. The formation is composed of uncompacted pebble, coarse grained conglomerate, sandstone and rare claystone. Pebbles generally consist of quartz, quartzite, rarely schist, metagranite and volcanite rock fragments. The unit was deposited in a fluvial environment. Based on seismic sections and well data, thickness of unit is $500 \mathrm{~m}$ (Siyako, 2006b). Considering its stratigraphic setting, the age of Kurcasalih Formation is Late Miocene-Pliocene (Çağlayan and Yurtsever, 1998) however, Pliocene age is more appropriate.

\section{Structural Geology}

It is known that structural lines that are described as Thrace fault system by Perinçek $(1987,1991)$ are right-lateral strike slip fault which were formed before the deposition of Ergene Formation. According to seismic data evaluation by Perinçek (1991), North Anatolian Fault in the Thrace basin was active before the Late Miocene. This fault was called from southeast to northwest as Kurklareli, Babaeski and Lüleburgaz Fault Zone (Figure 5). This fault system was active at the beginning of Late Miocene following the deposition of Danişmen Formation but before the deposition of Ergene Formation and en echelon structures were formed in association with this strike-slip fault system. Significant erosion was occurred along axes of these structures and particularly in the fault zones. Due to this erosion, in some parts of the basin Danişmen Formation was partly or completely eroded (Perinçek, 2010a, b, c; Perinçek et al., 2011). Ergene Formation that was

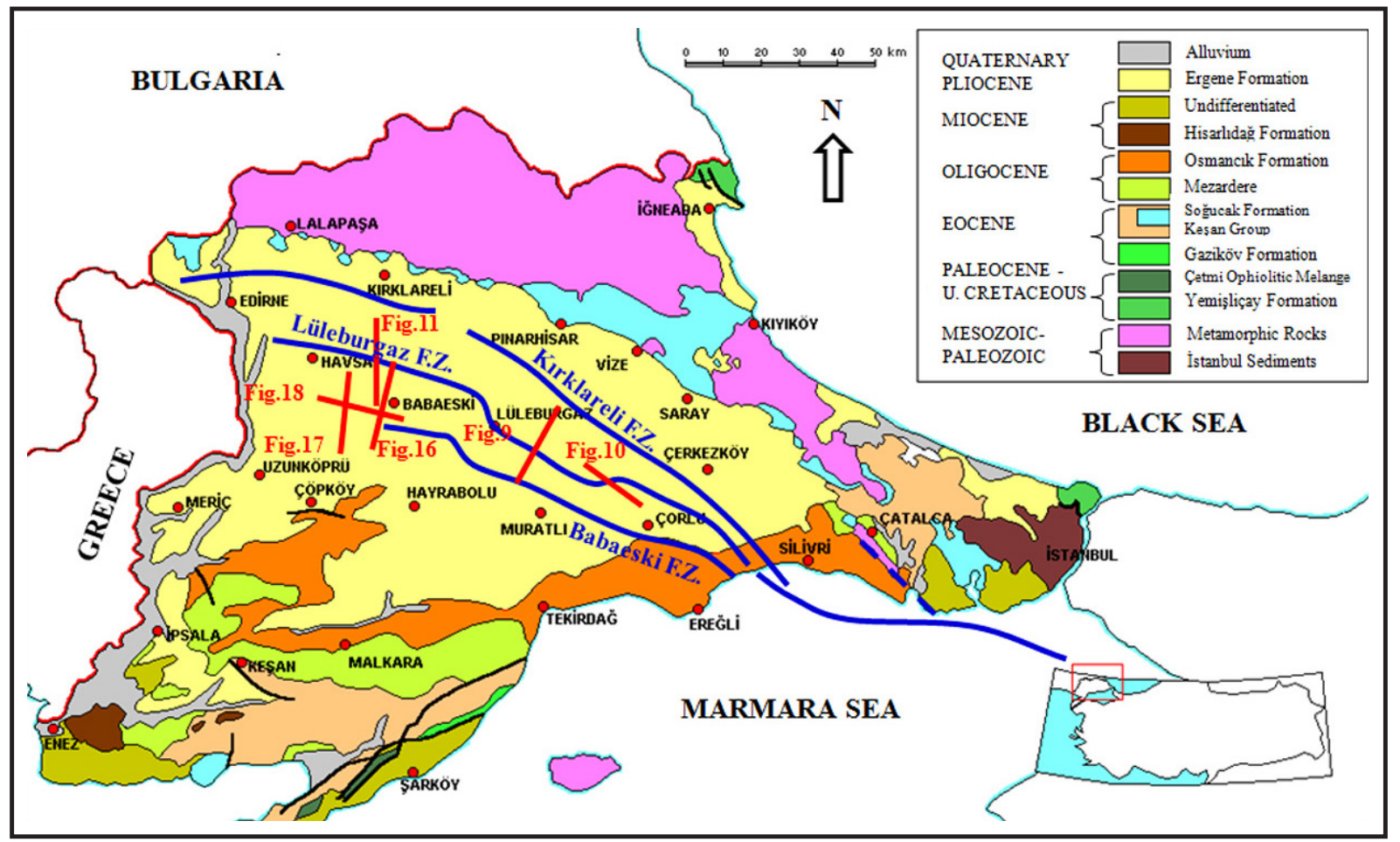

Figure 5 - Geology map of Thrace basin and Thrace fault zones (geology map: Kasar et al. (1983), fault lines: Perinçek, 1991; Perinçek, 2006). The Thrace fault system is buried under Late Miocene-Pliocene sequence (yellow colored in the map). 
deposited following the erosion (Hamitabat field) directly sets above the Osmanc1k Formation in some areas. In addition to erosion of Danişmen Formation in paleo-heights that were developed as a result of faulting, the Ergene Formation was deposited as thinner since these areas preserved their structural heights. The Ergene Formation is thick in synclines in depression areas. The activity of such faults was continued after the deposition of Ergene Formation (Perinçek, 1991 and 2006; Perinçek and Karslıoğlu, 2007) and in some areas at east of basin discordance plane at the base of Ergene Formation was folded as a result of compression caused by the fault activity (Perinçek, 1987 and 1991).

\section{The purpose and assessment of structure and thickness maps and their contribution to the project}

To understand the lignite potential of Danişmen Formation thickness and structure maps were formed. These maps are Osmancik Formation structure map (Figure 6), elevation map (paleo-topography) of discordance plane above the Danişmen Formation (Figure 7), thickness map of Danişmen Formation (Figure 8), total thickness map of lignite levels within the Danişmen Formation and thickness map of Ergene Formation. Each of these maps was considered regarding lignite potential under investigation.

\subsection{Structure map of the Osmancik Formation}

Structure map of the Osmancik Formation is important to show the proximity of upper contact of unit to the surface. Just above this unit is Danişmen Formation and therefore the extent of lower contact of this formation could only be known from this map. Using well data from TPAO structure map of the Osmancık Formation was prepared (Perinçek, $2010 b, c)$ (Figure 6). Red, orange and yellow colors on the map represent high lands, green and blue colors represent low-elevated areas and purple and pinkish colors stand for structural depressions (Figure 6). The most striking feature in the structure map of the Osmancik Formation is a SE extending paleoheight from Edirne to Akbaş, Haznedar, Mesutlua and Bayırtarla direction (Figure 6). This paleo-height partially disappears in SE direction but reappears around the Vakiflar well and continues ambiguously toward SE. Among the fault zones that are mapped as a continuation of NAFZ in Thrace region, the Lüleburgaz fault zone at the center has strike of WNW-ESE (Figures 5, 9, 10 and 11). It is shown in the structure map of the Osmanckk Formation that
(Figure 6) the long axis strike of this structural height matches with the orientation of Lüleburgaz fault zone (Perinçek, 2010a, b, c).

As a result, structural height is closely associated with fault system that cuts throughout the region. This map of regional scale clearly shows the relation between fault system and structural height. It is suggested that structural heights of Osmancik Formation should be considered for the lignite exploration. The Osmancik Formation is just below the Danişmen Formation and these two units are concordant. Therefore in high-elevated parts of the structure map of Osmanckk Formation, lignite levels within the Danişmen Formation are expected to be encountered at shallow depths. Such structural heights are possibly achieved at 0 to $700 \mathrm{~m}$ whilst structural depressions are found at depths of 2000$2700 \mathrm{~m}$. Lignite exploration works can be conducted in areas represented by yellow, orange, brown and red colors in figure 6. In other areas (green, blue, violet, and purple) the exploring of lignite layers at economic depths is quite limited.

\subsection{Map of discordance surface (paleotopography)} above the Danişmen Formation

Discordance plane above the Danişmen Formation was also mapped. This map may also be regarded as a paleotopography map. In the paleotopography map since discordance plane indicates areas of high elevation this map could also be useful tool for lignite exploration. Osmancik and Danişmen Formations are concordant and gradually transitional. Upper contact of Danişmen Formation is discordant and in some areas it is significantly eroded. Therefore structural maps of Osmancik (Figure 6) and Danişmen (Figure 7) formations are not the same (Perinçek, 2010a, b, c) because following the deposition of Danişmen Formation some parts of the basin are uplifted as a result of faulting and Danişmen Formation was eroded in these paleo-heights. As the amount of erosion increased in the Danişmen Formation the difference between the two structure maps becomes more distinct. In areas of limited erosion, for example at southeast of Edirne, the strike of anticline axis in structure map of Osmancık Formation is similar to that of Danişmen Formation. This similarity is also shown not in shapes but in strikes of synclines on both maps. In the area where erosion is intense and Havsa- 1 and Minnetler-1 wells drilled by TPAO (Figure 7) are located, there is a significant difference between the two maps. 


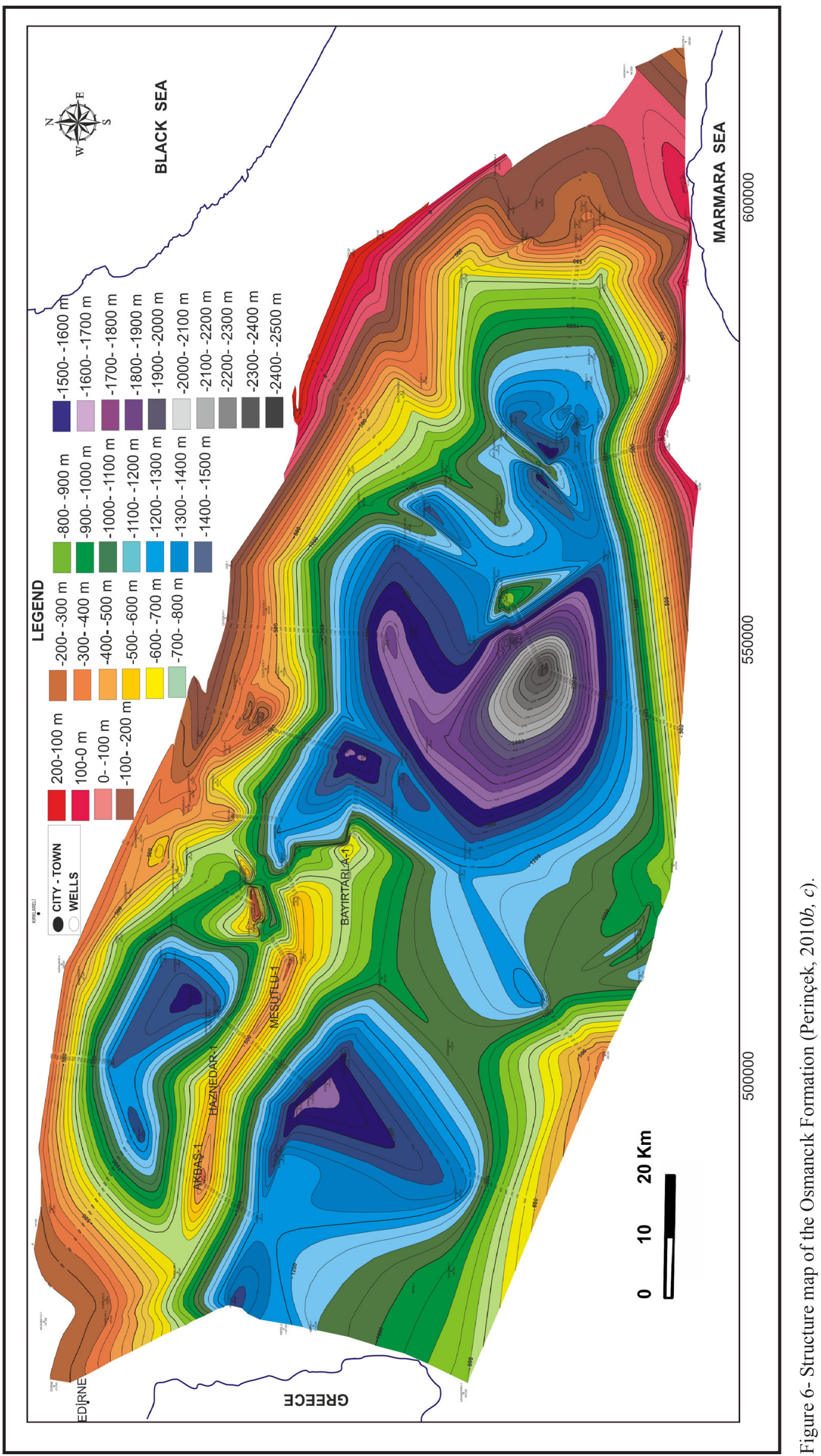


Factors Controlling Lignite Potential of Thrace Basin

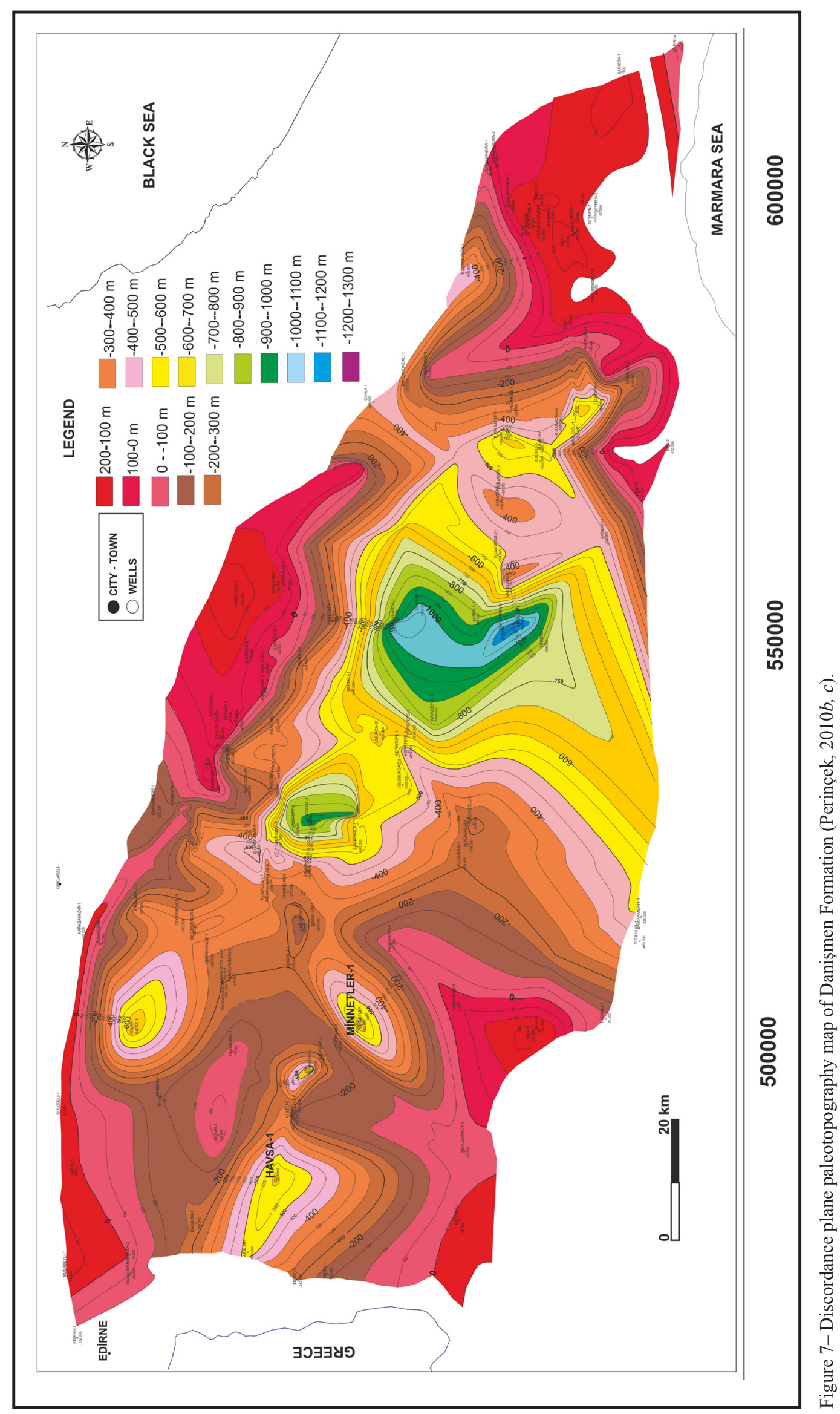




\subsection{Thickness map of Danişmen Formation}

Thickness distribution of Danişmen Formation in the basin is very important for lignite exploration. From this viewpoint, using the well data of TPAO thickness distribution of Danişmen Formation was made for the whole basin (Perinçek, 2010a, b, c) (Figure 8). This map shows the importance of erosion after the formation of Thrace fault system. Along the fault zone and in areas uplifted by the fault thickness of Danişmen Formation is lowered to 0 meter and in some areas it ranges from 0 to $300 \mathrm{~m}$. Maximum thickness of Danişmen Formation is $1600 \mathrm{~m}$. Purple, violet and blue fields in Figure 8 show areas where the formation is very thin or thin. Yellow and green areas stand for moderate thickness. Brown and red areas indicate the areas where the formation is the thickest. On this map the area where the unit extends from Edirne towards SE is quite distinct. The long axis strike of this area coincides with that of Lüleburgaz fault zone. Moreover, another area where Danişmen Formation is thin at south of Pinarhisar in northern margin of the basin, overlaps with Kurklareli fault zone (Figure 8). Uplift along the fault zone and subsequent erosion are the main reasons for thinning of Danişmen Formation. This erosion partly or completely removed the Danişmen Formation. Since lignite levels in this formation are also eroded lignite exploration should not be made in such erosional eras. In Kocagöl 1, İncibayır 1, Kumrular fields and in some parts of the Hamitabat field (Figure 8) thickness of Danişmen Formation is lowered to $0-100 \mathrm{~m}$ as a result of erosion activity. In figure 8, a small area is apparent at the center of region where the unit at southern and northern parts of the basin is very thick. The other thick section at north is between Kirklareli and Lüleburgaz fault zones. Danişmen Formation is also thick at south of Lüleburgaz fault zone. Its thickness at south is believed to be controlled by other factors rather than the fault zone. In this area Thrace basin is the deepest.

Thickness map of Danişmen Formation ends up with following results for the lignite exploration policy:

1. In paleo-heights of Thrace fault system, the Danişmen Formation was uplifted following the formation of fault system and then eroded. The NW-SE extending study area (green, blue, dark blue areas) at the center of map in figure 8 is related to abovementioned erosion. The area where Danişmen Formation along the northeast side of the map has a less thickness represents northeast margin of the Thrace basin. At present uplift formed by the Istranca Mountains on northeast of Thrace basin was land during the Eocene-Oligocene time.
Just southwest of this land Osmancek fault separates a shallow shelf from deeper part of the basin. While Eocene-Oligocene units were deposited in the basin, the Osmancik fault was active, at the and of middle Miocene as a result of activation of NAFZ. Osmanck fault reactivated again. Osmancik fault significantly overlaps with Kurklareli fault zone. The reason for the absence or thinning of Danişmen Formation at northeast of Thrace basin (Figure 8) is that when this unit was depositing the area was a part of basin margin or it was a shore. In southern part of map in figure 8 Danişmen Formation gets thinner due to a structural reason. Although this area between Silivri and Tekirdağ along the coast of Sea of Marmara corresponds to deeper part of Thrace basin, Danişmen Formation gets thinner southward. This can be attributed to structural paleo-height caused by NAFZ during Late Miocene-Pliocene. As a result of this uplift, the area between Silivri and Tekirdag was uplifted where Danişmen Formation was completely and Osmancik Formation was partly eroded. Seismic sections for this area clearly show uplift and associated erosion.

2. As a result of uplift caused by the Thrace fault system upper and middle parts or the whole Danişmen Formation were eroded. While NAFZ was active during Middle Miocene in Thrace basin, en echelon structures were formed oblique to the fault zone. The Hamitabat gas field is the best example for this (Figure 8). In some wells in this field Danişmen Formation was completely eroded, and therefore lignite layers are absent in this area. Structural factors associated with NAFZ are responsible for this erosion. Lignite layers within the formation are found in middle part of the sequence and just above this part. Therefore the degree of erosion should be evaluated carefully. Particularly at the center and southern margin of Thrace basin erosion is very intense. In these areas if thickness of Danişmen Formation is 0 to $400 \mathrm{~m}$, lignite levels may have been completely eroded. Along the NE margin of Thrace basin the unit is quite thin but thinning is not related to erosion. In this area, although Danişmen Formation is thin economic lignite levels may be found in suitable facies.

3. In figure 8 in yellow, orange, red, brown and maroon colored areas Danişmen Formation has thickness of 700 to $1700 \mathrm{~m}$. If thickness of Ergene Formation above the Danişmen Formation and thickness of lignite-free level in upper part of Danişmen Formation are added to each other, it becomes difficult to find lignite levels at economic depths. For this reason, thickness distribution of 


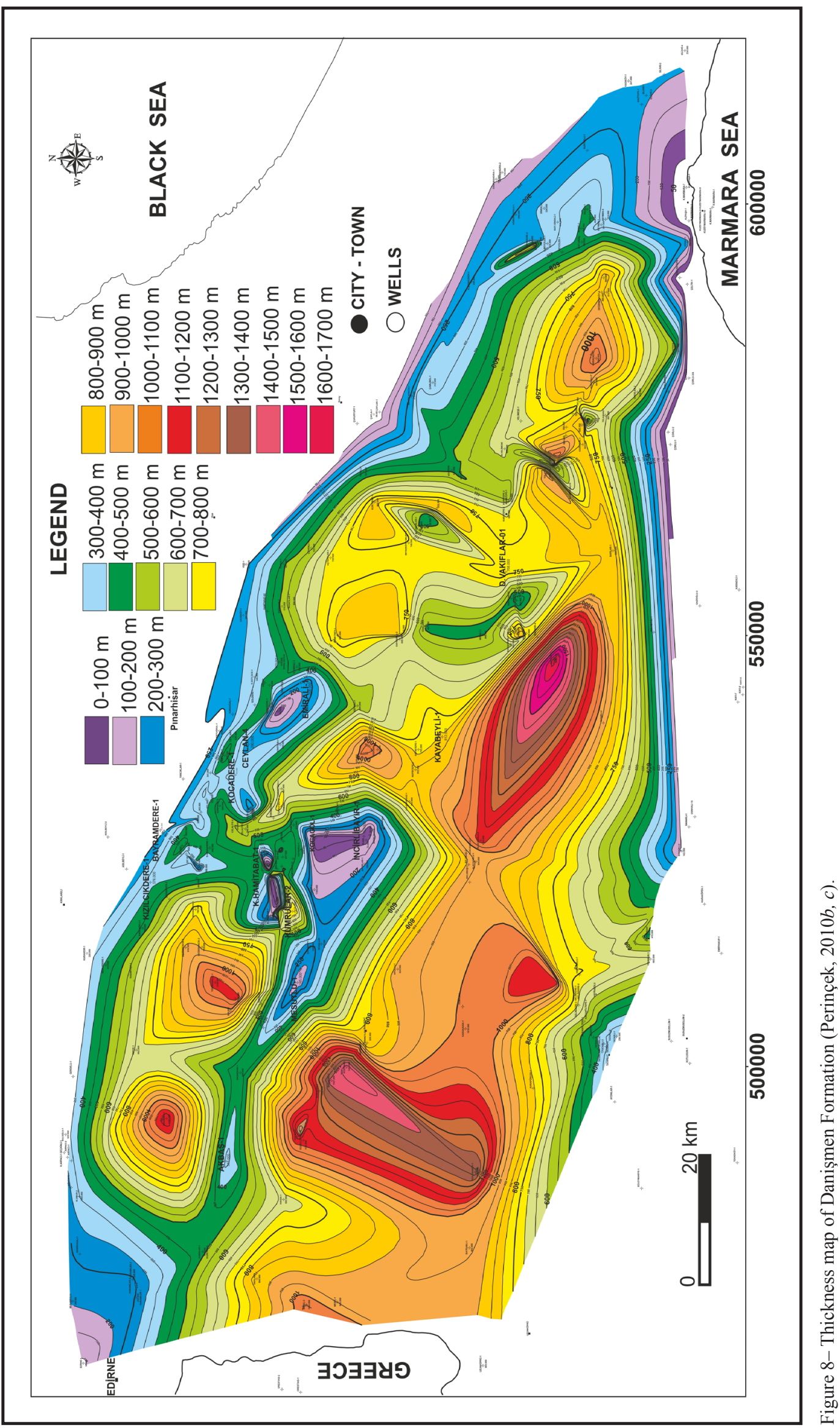


Danişmen Formation should be carefully reviewed. In central and southern part of the basin, it must be stayed away from areas where unit is thinner than $400 \mathrm{~m}$ and thicker than $1000 \mathrm{~m}$. This finding should be considered for lignite explorations works to be conducted in the coming years.

4. In thickness of map of Danişmen Formation in figure 8, this formation is thinner along the Akbaş 1-Mesutlu 1-İncilibayır 1 line due to Lüleburgaz fault zone traversing this area (Figure 5). In structure map of Osmancik formation around the same line (Figure 6) it is also observed as paleo-height. Continuation of the same fault zone extends around the Kayabeyli-1 and Vakiflar wells in eastern half of the map (Figure 8 ) and erosion effect arising from paleo-height by the fault system is apparent. Around Vakıflar Danişmen Formation is thin and as a result of erosion in this area lignite layers are completely removed. In this area NW-SE extending linearity was formed by the Lüleburgaz fault zone and its orientation is nearly the same as this fault zone. Along this fault zone a number of 3 seismic lines (Figures 9, 10 and 11) were reviewed which showed the importance of erosion. Considering the results of these seismic sections, it is favorable to have a lignite exploration license around

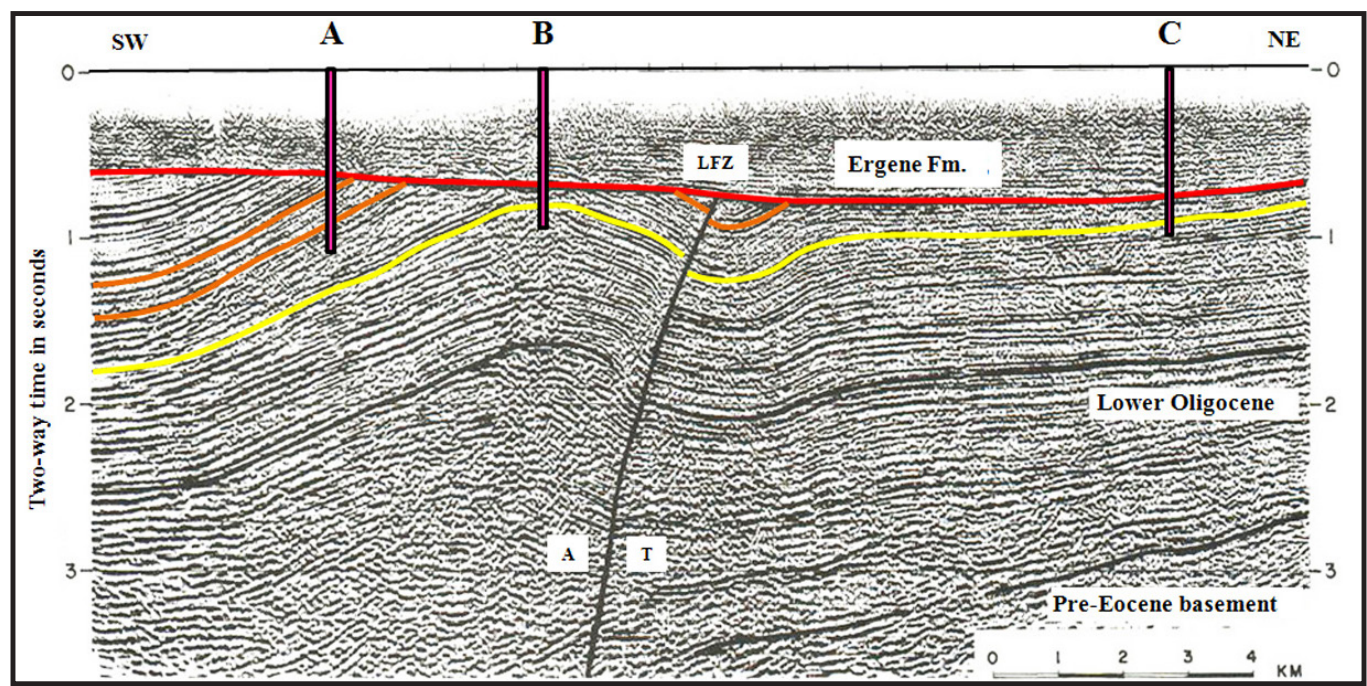

Figure 9 -Lüleburgaz Fault Zone (LFZ) is shown in seismic line (see Figure 5 for location). Right (T) and left (A) parts of the fault move towards the reader and from the reader, respectively (compiled from Perinçek, 1991; 2006).

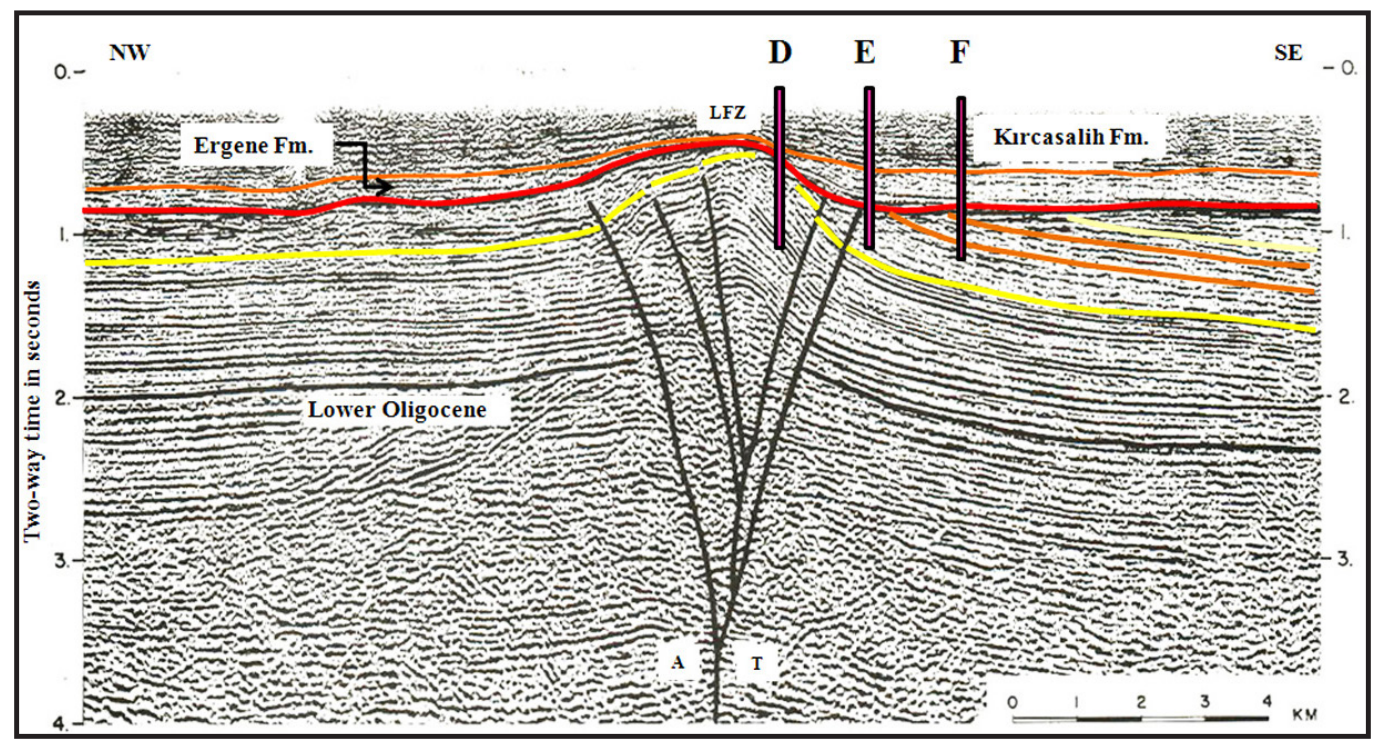

Figure 10 - Lüleburgaz Fault Zone (LFZ) is shown in seismic line (see Figure 5 for location). (Compiled from Perinçek, 1991; 2006). 


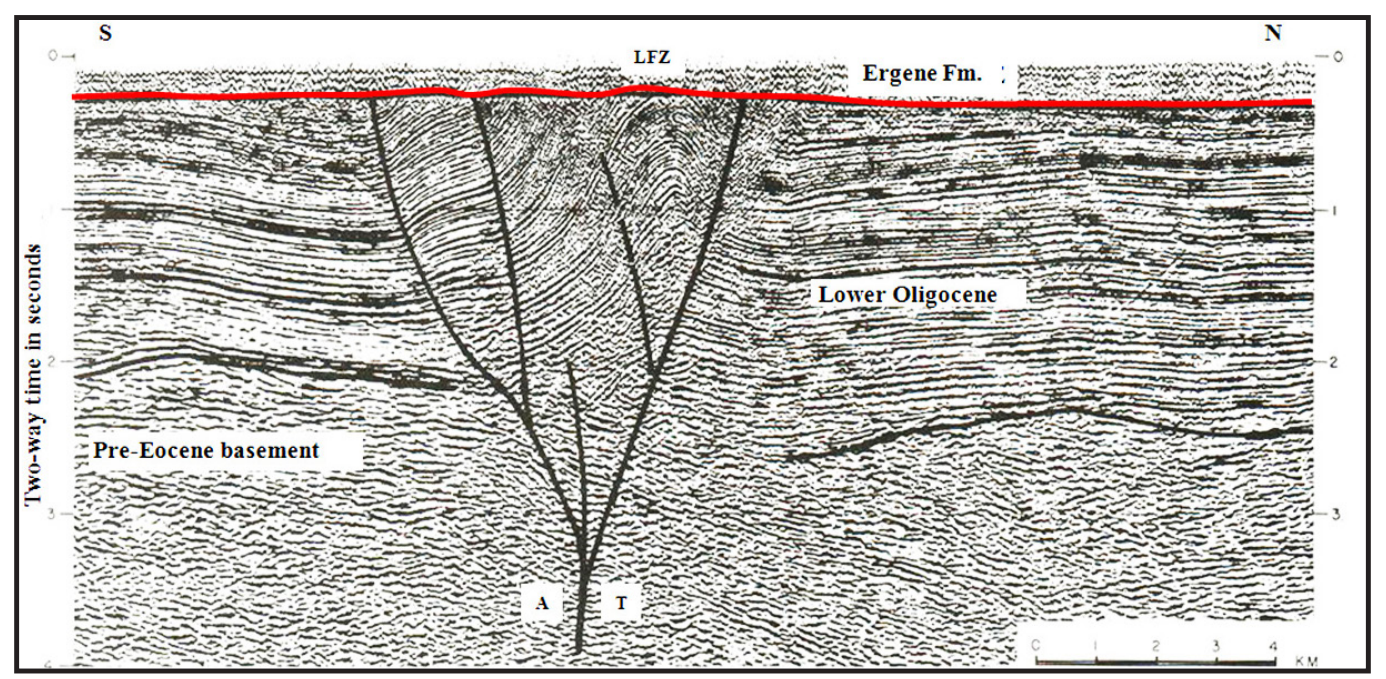

Figure 11 - A positive flower structure is shown around Havsa in western part of the Lüleburgaz Fault Zone (LFZ) (compiled from Perinçek, 1991; 2006).

the Mesutlu-1 well (Figure 8).

Danişmen Formation is thin around the Kizilcıkdere 1, Bayramdere 1, Kocadere 1, Ceylan 4, and Emirali 1 wells (Figure 8). The Kirklareli fault zone, which is northernmost branch of NAFZ at the end of Middle Miocene-Late Miocene (Figure 5 ) extends in the vicinity of above mentioned wells. This is another good example for uplift and erosion associated with this fault.

In seismic section given in figure 9, the Lüleburgaz fault zone (LFZ) is shown at the center (Perinçek, 1991). It was assumed that reflector indicated by yellow color represents a level close to the base of Danişmen Formation and two different levels in the same section indicated by orange color are the lignite layers. Approximate lignite depth is hypotheticial to explain erosion problem in the region. The reflector indicated by red color further above is an angular discontinuity at the base of Ergene Formation. An anticline at the left was formed concurrently with the fault activation and erosion was taken place along the anticline axis after the uplifting. The discordance plane that formed after the fault was not folded. This indicates that fault in this area did not move following the deposition of Ergene Formation. The erosion that occurred after the formation of anticline is quite noticeable in the seismic section. It is clearly shown in seismic section that in the well designated by B symbol first Ergene Formation is encountered and then Danişmen Formation is cut further below the discordance. At point B upper part of Danişmen Formation is completely eroded meanwhile lignite layers indicated by two orange lines are also removed.
In conclusion, lignite will not be cut in the presumed $B$ well. In well A at left of B hypotheticial well, lignite will be most probably encountered. In the presumed well C lignite layers will not be cut since Danişmen Formation is significantly eroded.

The flower structure shown in figure 10 was developed in compression buckling along the fault zone. Following the first activation of fault Ergene Formation was deposited in the Middle-Late Miocene and discordance at the base of this formation was folded and then Kurcasalih Formation was deposited in Pliocene and finally discordance plane comprising the Pliocene sequence was folded since fault system continued its activation. While Ergene and Kurcasalih Formations were deposited at east of Thrace basin the movement continued along the Thrace fault system. In seismic section given in figure 10 the level indicated by yellow color is assumed to represent reflector that is close to the base of Danişmen Formation. Two orange reflectors at right side of section represent proposed lignite levels. The angular unconformity at the base of Middle-Late Miocene Ergene Formation was marked with red color. Although this unconformity plane in figure 9 is not folded, discordance plane in red color in seismic section in figure 10 is shown to be folded. Folding of discordance plane is not common to western part of basin but around Vakıflar wells and Silivri in eastern part of basin. Following the deposition of Ergene Formation, the fault was reactivated and thus discordance plane was folded (Perinçek, 1991 and 2006). The positive flower structure shown at the center of figure 10 is related to compression buckling of lateral strikeslip faulting. When the seismic section is evaluated 
by means of lignite potential, it is predicted that in well D following a thin layer of Ergene Formation directly Osmancik Formation is cut. In this case, in the proposed well D Danişmen Formation is probably completely eroded. In well E shown in Figure 10 after the Ergene Formation and discordance lower part of Danişmen Formation will be cut. Therefore, due to erosion no lignite level is expected in well $\mathrm{E}$. In the proposed well $\mathrm{F}$, after the Ergene Formation and discordance Danişmen Formation with lignite interbeds is possibly cut. From well F to southeast direction the thickness of Danişmen Formation above the lignite levels will be increased. Considering the thickness of overlying Ergene Formation, it seems difficult to find any lignite level at economic depths at right part of the section (Perinçek, 2010a, b, c).

In figure 11 uplifting along the fault zone, anticline formation and subsequent erosion are apparent. Due to erosion, in an area parallel to the fault zone thickness of Danişmen Formation is decreased and locally lowered to $100 \mathrm{~m}$ and occasionally become zero. In association with erosion, lignite levels in middle part of Danişmen Formation are also removed. As shown from figure 9, discordance plane in this section was not also folded. After the fault formation, no tectonic movement was occurred along the fault zone. Positive flower structure of Lüleburgaz fault zone is shown in figure 11. The area of positive flower structure (the area of Aktaş-1, Haznedar-1 and Mesutlu-1 wells between and around Havsa-Babaeski; Figures 6 and 10 ) is the upliftted part and erosion area along the Lüleburgaz fault zone. The interpretation for seismic section in figure 9 and 10 is also valid for this section. There is little possibility to cut any lignite layer at the center of the positive flower structure. Wings of this structure are potential sites for lignite. New license areas proposed by this study are at the wings of aforementioned structure.

\subsection{Total thickness map of lignite for the Danişmen Formation}

Thickness map of lignite, as expected, will be proper for the aim of study if it is made in the regional scale, therefore, thickness map was made for the whole Thrace region. This map may be regarded as a kind of facies map since it shows swamp and lake areas where lignite is accumulated. Due to facies change of lignite levels and erosion there is a discontinuity in the lateral direction.

During the construction of lignite thickness map, two different data sets were used. The first is total thickness map of lignite using TPAO well data. The second is lignite thickness map using MTA and TKI well data. At the beginning of project these two maps were drawn separately. Considering the total lignite thickness there are inconsistencies between these maps.

Lignite thickness within the Danişmen Formation is controlled by 2 important factors. In thickness map using TPAO data (Figure 12) and revised thickness map using MTA and TKI data (Figure 13) there is no lignite in areas shown by blue color. There are two reasons for the absence of lignite. The first is facies change in the Danişmen Formation.

During the deposition of Danişmen Formation lignite was formed in swamp and lake areas but not in the fluvial deposits where conglomerate and sandstone were accumulated. In figure 14 absence of lignite in blue colored areas is attributed to facies changes in the Danişmen Formation. The Danişmen Formation at north of Demirhanlı 1well is represented by siltstone, sandstone, and conglomerate which change to clay, siltstone and marl towards the east (Figure 14). As a result of decreasing of clastic content in the sequence marl was deposited in a low-energy environment which is represented by swamp areas. Therefore at south of Demirhanlı 1well lignite with thickness of $5 \mathrm{~m}$ was accumulated in clay and marls. In this map it is shown that lignite thickness is between $0-7 \mathrm{~m}$. For instance, for a distance of $500 \mathrm{~m}$, total lignite thickness might change from 0 to $7 \mathrm{~m}$ which create difficulties in the lignite exploration works.

In the area of Hayrabolu wells (Figures 12 and 13) no lignite was found because of unsuitable conditions of Danişmen Formation for the lignite formation. Although lignite is absent in this area the thickness of Danişmen Formation is $600-1000 \mathrm{~m}$. This region is at south of Thrace fault system and therefore the reason for absent of lignite is not relate to erosion but deposition.

Another reason is related to structural evolution of the basin. Significant erosion was occurred along structural heights and faults that developed in Middle Miocene as a result of activity of Thrace Fault System. The thickness of Danişmen Formation on the structural heights becomes thin by erosion (Figure 8) and accordingly lignite layers were disappeared.

When the total lignite thickness map is prepared and well data of MTA, TKI and TPAO are evaluated following issues were taken into account (Perinçek, Perinçek, 2010a, b, c); 


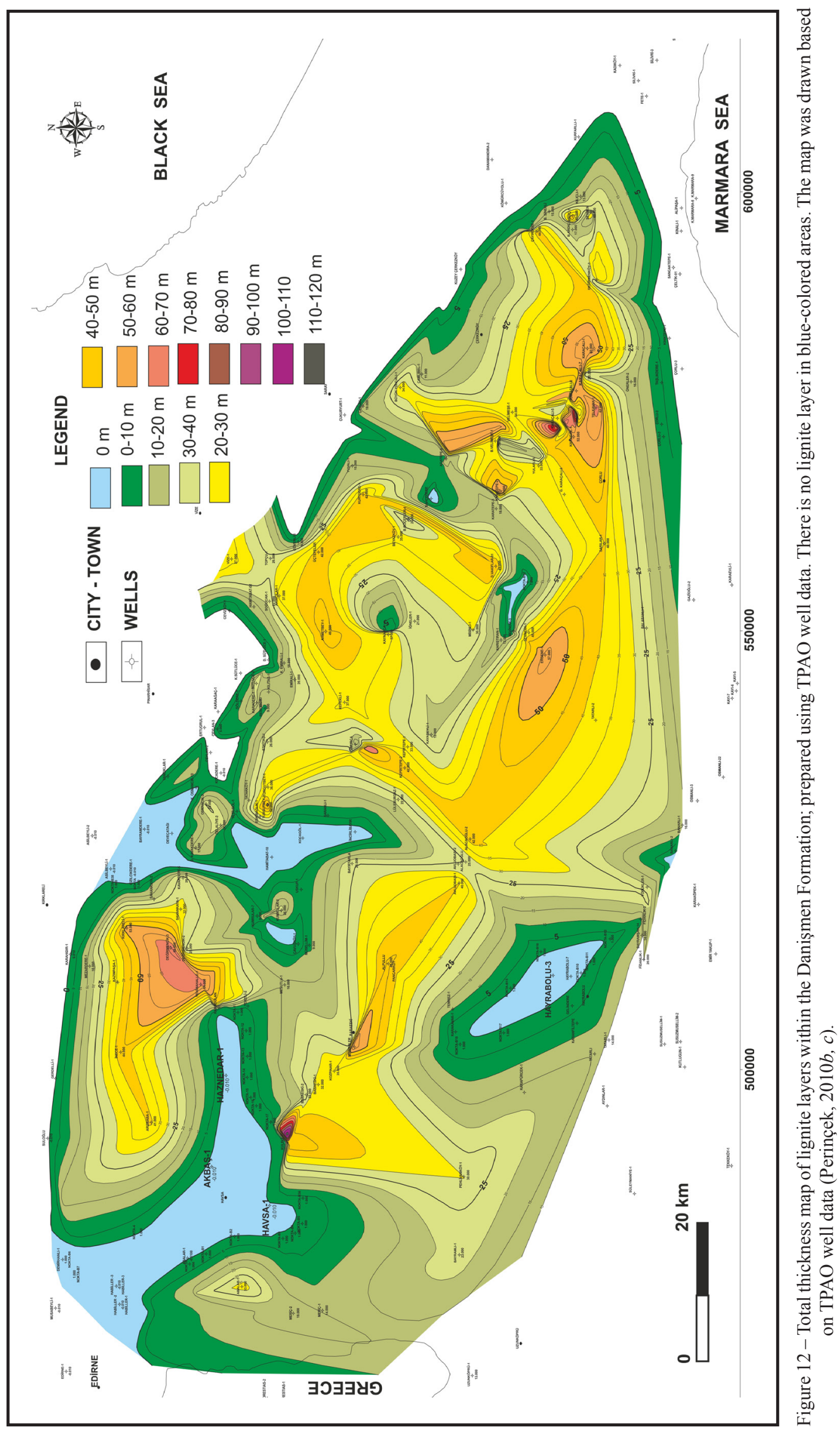




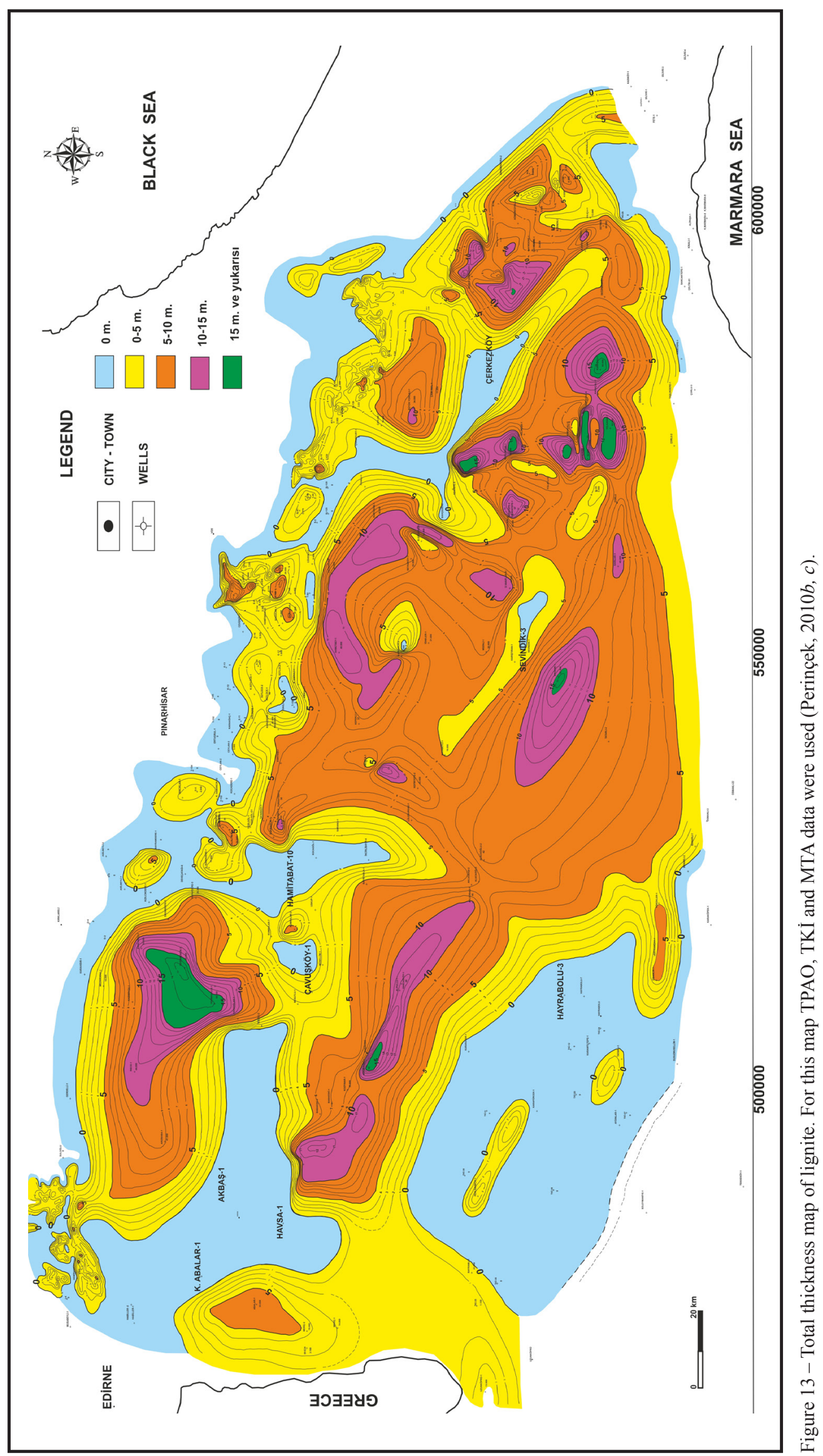




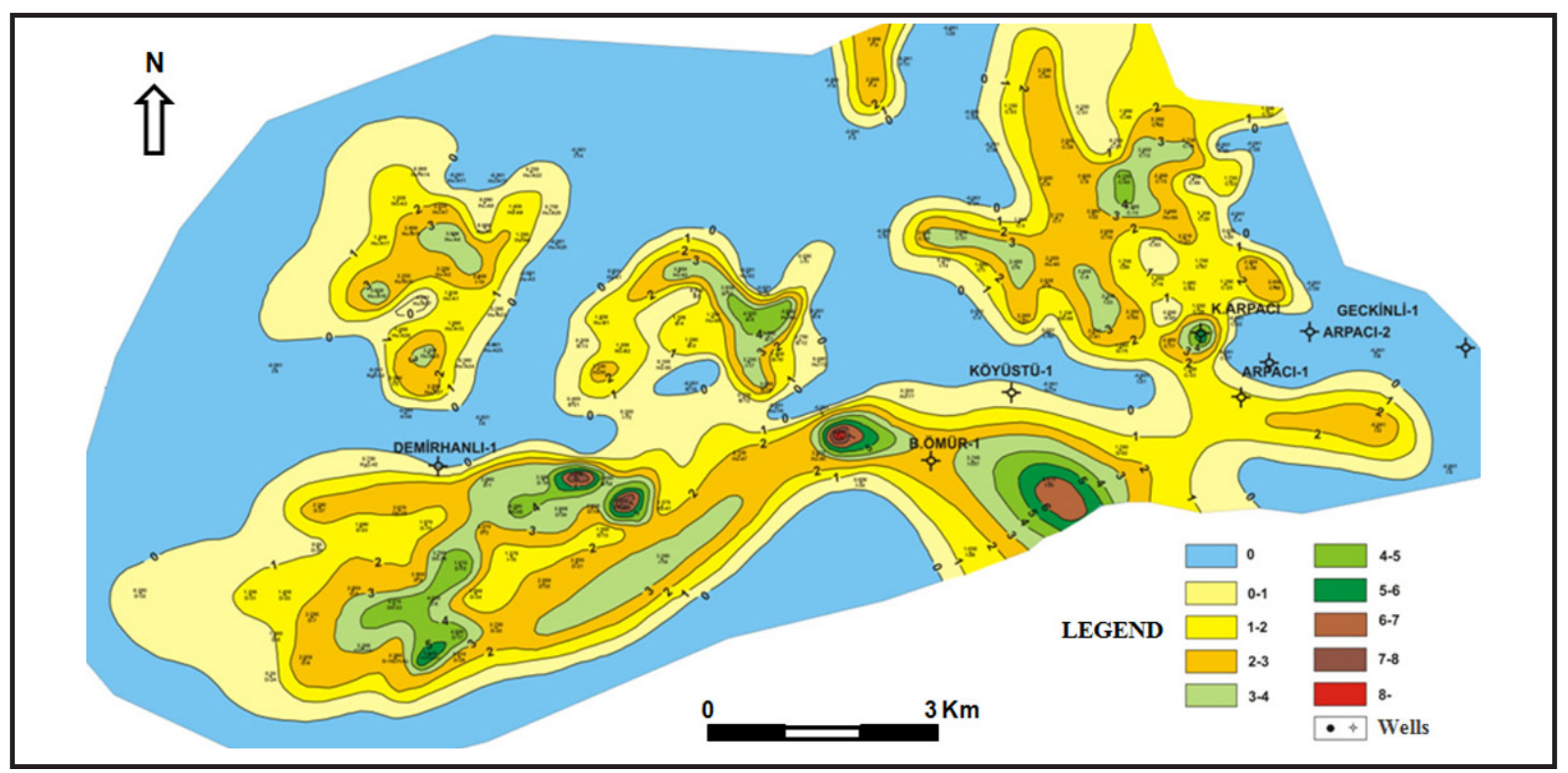

Figure 14 - Total thickness map of lignite levels within the Danişmen Formation between Süloğlu -1 and Musabeyli-1 wells at southeast of Edirne (Perinçek, 2010b, c).

1- The total lignite thickness map based on TPAO data contains some discrepancy since the area of interest of TPAO is not the coal. Therefore thickness values in this map do not properly serve the aim of study. Nevertheless the "Lignite Thickness Map" based on TPAO data was instructive at the beginning since it indicates the lignite-dense areas (Figure 12). In TPAO wells lignite thickness was generally shown higher because no core sample was taken from lignite levels since the Danişmen Formation is not the target formation. The Danişmen Formation was progressed with diamond drilling and only cutting off samples were taken. During the drilling following the progress of lignite level, failure occurs in the overlying lignite levels and the material fell down reaches at the bottom and recycled to the surface which makes an impression that lignite is continuously intercepted. In TPAO wells claystone levels with high lignite content, ligniferous shale and ligniferous claystone levels are also progressed as lignite. Consequently, lignite thickness cut in the wells is found much thicker in the composite well logs. In TKI and MTA wells ligniferous levels are progressed with coring the thickness of lignite cut in the wells are reliable. Therefore lignite thickness map obtained from TPAO data was reviewed considering the geologic data of region and total lignite thickness map constructed with TPAO and TKI-MTA well data was revised and integrated. Then the revised TPAO lignite thickness map (Figure 12) was combined with total lignite thickness map established by TKİMTA data. During this process, thicknesses in wells with coring were considered and lignite thicknesses in TPAO wells were reduced. The map used in this study (Figure 13) is the revised lignite thickness map. In areas where TKI, MTA and TPAO wells are close to each other TPAO wells were compared with TKI and MTA wells and the their ration was examined. It was shown from the results of this work that lignite thickness in TPAO wells is about 3-4 times greater than those of TKI and MTA wells. The area which hosts wells of different organizations is in northeast part of Thrace basin. In these areas TPAO well data are compared with MTA and TKI data and using the resulting ration TPAO thicknesses were evaluated by dividing 3 or 4 and the new total lignite thickness map was established (Figure 13). When making this proportioning process, these values were obtained by dividing lignite thickness in some TPAO wells by 2 or 5 . In doing this, geologic information of the basin, particularly structural setting, was taken into account which greatly contributed to the map. Total lignite thickness map given in Figure 13 was constructed with solely interpretive contouring without using computer program. During the contouring thicknesses from TPAO data were reduced with respect to the closest MTA and TKI well. Therefore, reduction rate is different for each well. During the interpretive contouring, structural setting of Kırklareli, Lüleburgaz and Babaeski fault zones was considered.

Thicknesses selected for above mentioned rations and used in the present thicknesses are given in table 1 and ordering in the list is from northwest to northeast of the basin. The first value in table is the one shown in TPAO wells and the second is calculated using a proportion. 
Table 1- Thickness of lignite cut in TPAO wells and some examples for calculated thicknesses.

\begin{tabular}{|l|c|c|l|c|c|}
\hline \multicolumn{1}{|c|}{ Well name } & $\begin{array}{c}\text { TPAO } \\
\text { Thickness meter }\end{array}$ & $\begin{array}{c}\text { Thickness used, } \\
\text { meter }\end{array}$ & \multicolumn{1}{|c|}{ Well name } & $\begin{array}{c}\text { TPAO } \\
\text { Thickness meter }\end{array}$ & $\begin{array}{c}\text { Thickness used, } \\
\text { meter }\end{array}$ \\
\hline Adalar 1 & 33 & 5 & Kepirtepe 2 & 42 & 9 \\
\hline Ăğrubaba 1 & 41 & 9 & Turgutbey 2 & 52 & 10 \\
\hline İnece 1 & 44 & 10 & Ahmetbey 1 & 49 & 11 \\
\hline Kırklareli 1 & 53 & 13 & Doğuvakıflar 1 & 45 & 10 \\
\hline Değirmencik 3 & 86 & 17 & Sarılar 1 & 40 & 10 \\
\hline Kozpınar 1 & 35 & 8 & Karatepe 1 & 52 & 12 \\
\hline Babaeski 1 & 32 & 7 & Kurtdere 1 & 42 & 9 \\
\hline Alpullu 1 & 46 & 12 & Üçtepeler 1 & 42 & 9 \\
\hline Avluobası 1 & 40 & 10 & Büyükyoncalı 1 & 34 & 10 \\
\hline Alacaoğlu 2 & 42 & 9 & Telkavak 1 & 62 & 15 \\
\hline Lüleburgaz 1 & 22 & 5 & Karaçalı 1 & 60 & 16 \\
\hline
\end{tabular}

2- At the first stage of project, well correlation was made in the Thrace region and it was found that, because of insufficient well depth, lignite zones in some MTA and TKİ wells are not penetrated which are encountered in lower parts of TPAO wells. In the thickness map given in figure 13 lignite levels that are cut in lower parts of TPAO wells are not taken into account. Therefore total lignite thickness map given in Figure 13 represents minimum total lignite thickness. Based on data available, Figure 13 yields the pessimist thicknesses for the lignite levels.

3- The northern part of total lignite thickness map (Figure 13) could be processed in detail because of intense number of core samples and well data. In northern areas where intense well data are available areas without lignite layers are easily recognized. Thickness variations in these areas reflect facies distribution within depositional basin of Danişmen formation. For example, in blue areas in figure 14 absence of lignite is explained with facies characteristics. Structural factors controlling the lignite thickness is very limited. The kind of detail cannot be mentioned for central and southern Thrace regions. In central and southern Thrace regions, the areas where lignite levels are absent (blue areas in figure 13) are eroded and uplifted due to the Thrace Fault System (Kurklareli, Lüleburgaz and Babaeski Fault Zones) which is a continuation of NAF. Therefore lignite thickness in central and southern parts of this map does not truly reflect the facies changes in the Danişmen formation. In some areas lignite might not be widespread as shown.

4- Lignite levels within the Danişmen formation are mostly found in middle section. In areas where the formation is eroded lignite levels are also eroded. Consequently in total lignite thickness map given in Figure 13, the areas where lignite is absent correspond to thin levels of Danişmen formation in total lignite thickness map. In other words, there is no lignite in areas where Danişmen formation is thin. The Kuzey Abalar 1, Aktaş 1, Havsa-1, Çavuş Köyü 1, Hamidabat-10, Çerkezköy and Sevindik 3 TPAO wells do not have any lignite level (Figure 13).

5- Lignite layers mostly occur in marl. Pebbly, sandy and carbonaceous levels do not contain lignite. In addition, lignite is also absent in areas of widespread shale levels.

\subsection{Total thickness map of Ergene and Kircasalih formations:}

Thickness of Ergene Formation is the first obstacle to access the lignite. In order to examine the change of thickness of this formation within the basin, thickness map of Ergene Formation was established throughout the Thrace Basin (Figure 15). In TPAO and some MTA and TKİ wells, the Ergene Formation and overlying Kurcasalih (Thrace) Formation could not be differentiated. Therefore thickness of Kircasalih Formation was included to the thickness map of Ergene Formation. Consequently, when mentioned the thickness map of Ergene Formation total thickness map of both formations are meant. Examination of some seismic sections in the Thrace Basin reveals dicorformity between the two formations (Figure 10). This unconformity is not recognized everywhere. The lithologies of Kircasalih (Thrace) and Ergene formations are similar which complicates distinguishing these units in the field. On the recent MTA and TPAO geology maps these units were mapped separately. 


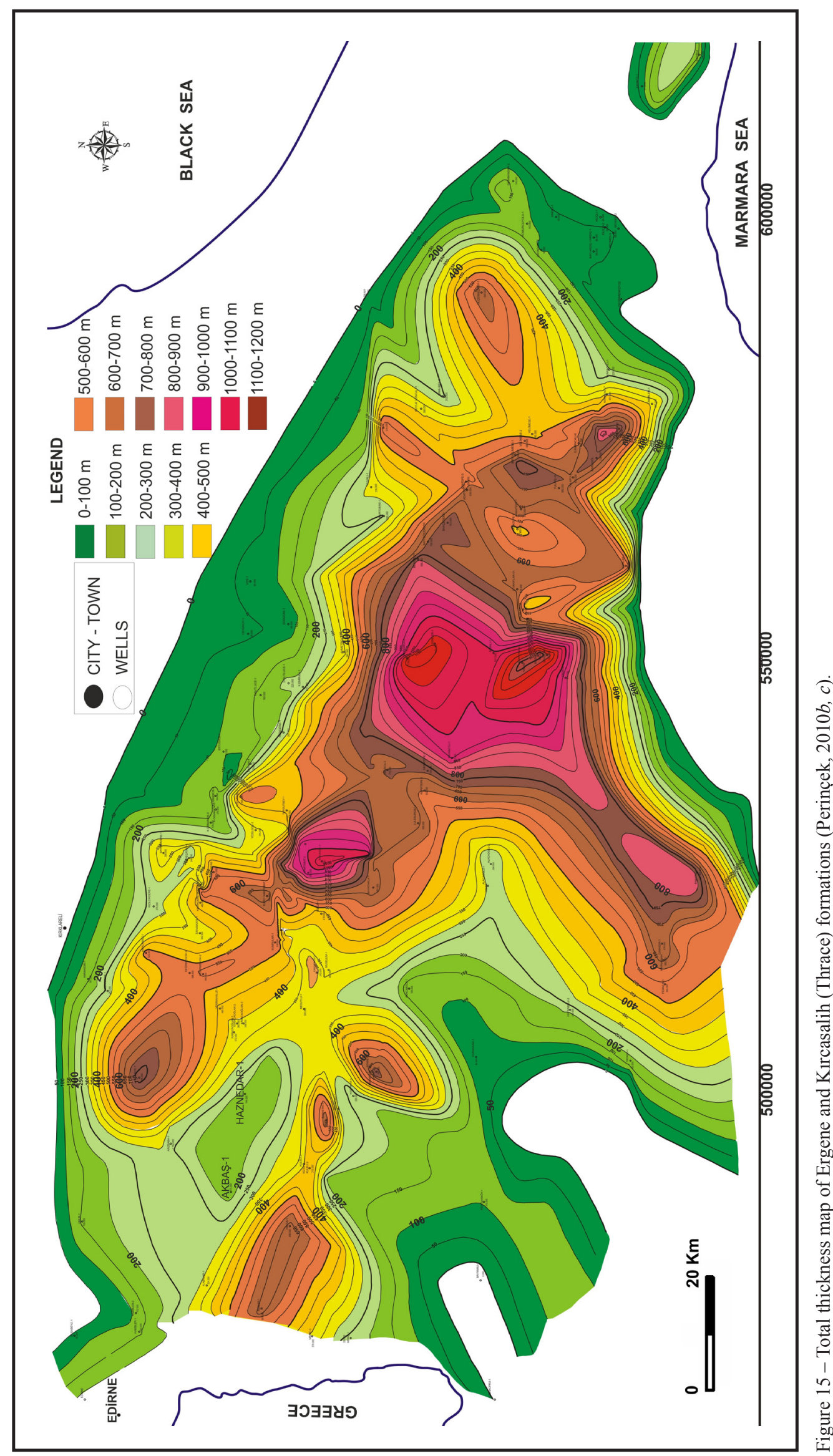


In the green colored are shown in Figure 15 total thickness of Ergene and Kurcasalih formations is 0-300 m. yellow and dark yellow colors represent thickness of $300-500 \mathrm{~m}$, orange color $500-800 \mathrm{~m}$ and brown and red colors represent $800-1200 \mathrm{~m}$. The areas where Ergene Formation is thicker than $500 \mathrm{~m}$ are not suggested for obtaining permit and drilling. The thickness of Ergene Formation is controlled partly by the activity of NAF in the Thrace basin. In paleo-heights comprised by the fault (around Akbaş 1 and Haznedar 1 wells; Figure 15) the Ergene Formation is thin. In addition, it is known that Ergene Formation is also thin along the margins of Thrace basin. A few permits at south of Vize are suggested to be abandoned since Ergene Formation in these areas is thicker than $500 \mathrm{~m}$. At these sites lignite thickness may be economic but not at feasible depths.

The Ergene Formation was deposited on paleoheights which are formed by structural events occurring along the Thrace Fault System which is the oldest branch of NAF. During the deposition some paleo-heights that formed by the effect of NAF were coincided in the last stages of deposition of Ergene Formation and therefore in these areas the unit is thin (Perinçek, 2010a, b, c) (Figure 10). The Thrace Fault System was reactivated following the deposition of Ergene Formation between Vakıflar-1 and Istanbul at east of Thrace basin and discordance plain at the base of Ergene Formation was folded together with Ergene Formation (Figure 10) and as a result the formation was partly eroded. New paleo-heights occurring in erosional areas represent thin parts of the Kurcasalih formation. Following the deposition of Kurcasalih formation activity of fault was continued on the Thrace Fault System. Following this activity the Kircasalih formation slightly inclined and folded. This activity is shown in eastern parts of the Thrace basin since this area is close to the Sea of Marmara where NAF is active.

\section{Assessment of Seismic Data}

Seismic sections provided to TKİ by TPAO were evaluated and areas where lignite layers close to the surface were identified (Perinçek 2010a, b, c). Assessment of these sections was done for the area (around Babaeski) between TKI licenses at south of Pehlivanköy and licenses around the Karacaoğlan town. Section nos MAD-84-411 (Figure 16), MAD84-432 (Figure 17) and MAD-84-413 (Figure 18) are included to this report. Well data (Babaeski 2, Minnetler 1) were transferred to the seismic sections using seismic-time data. Reflection plane shown with orange color in sections represents the base of Ergene formation (above the Danişmen Formation). Green levels in sections are the lignite layers. Reflection planes indicated with green may contain lignite around the well but green reflection continuing in lateral direction does not necessarily mean the presence of lignite along the seismic line. In other words, levels indicated by green colors and represented by lignite in the wells show lateral facies change and may change to marl or clay. In these sections, planes with lignite levels were traced and the areas where these layers get close to surface were identified. If there is no lateral facies change it is possible that green levels are

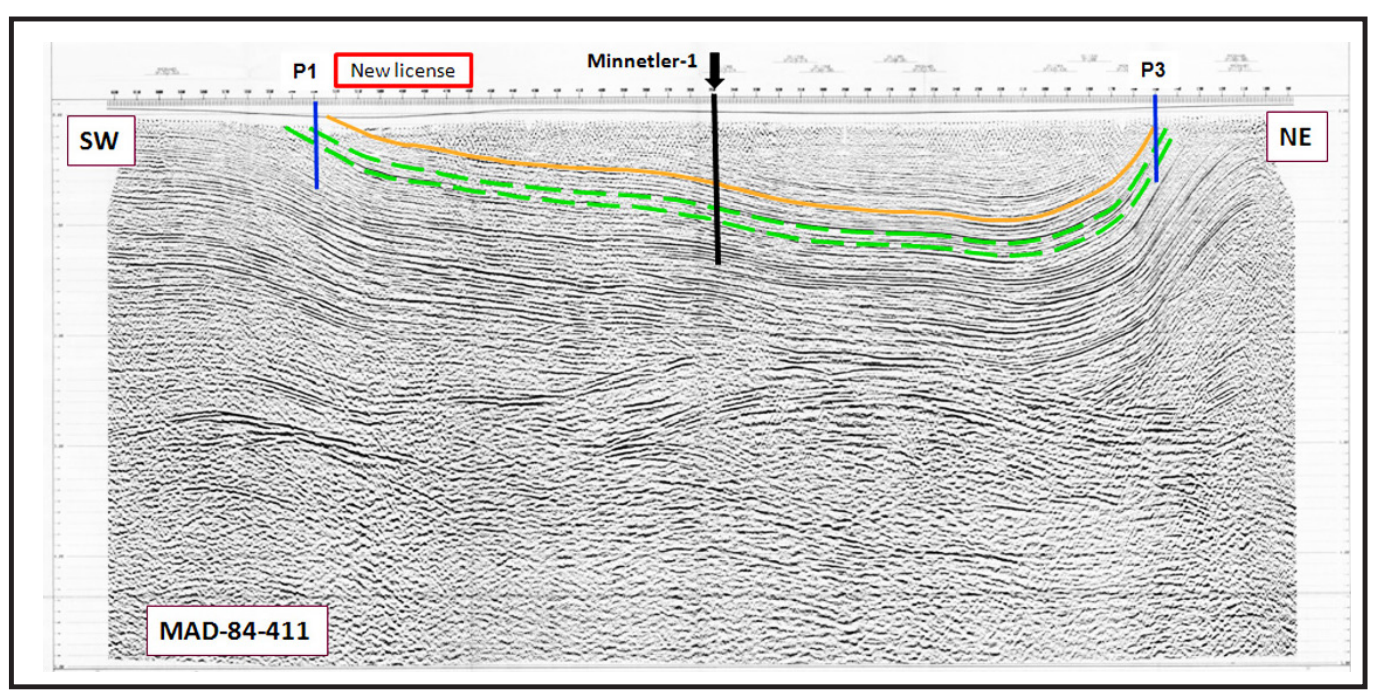

Figure 16 - Seismic section no MAD-84-411. Lignite layers (green) and the base (top of the Danişmen Formation) of Ergene Formation (orange) are marked on the section. Proposed P1 well is southwest of section and P3 well is at northeast (for locations see Figures 19, 20 and Figure 5). 


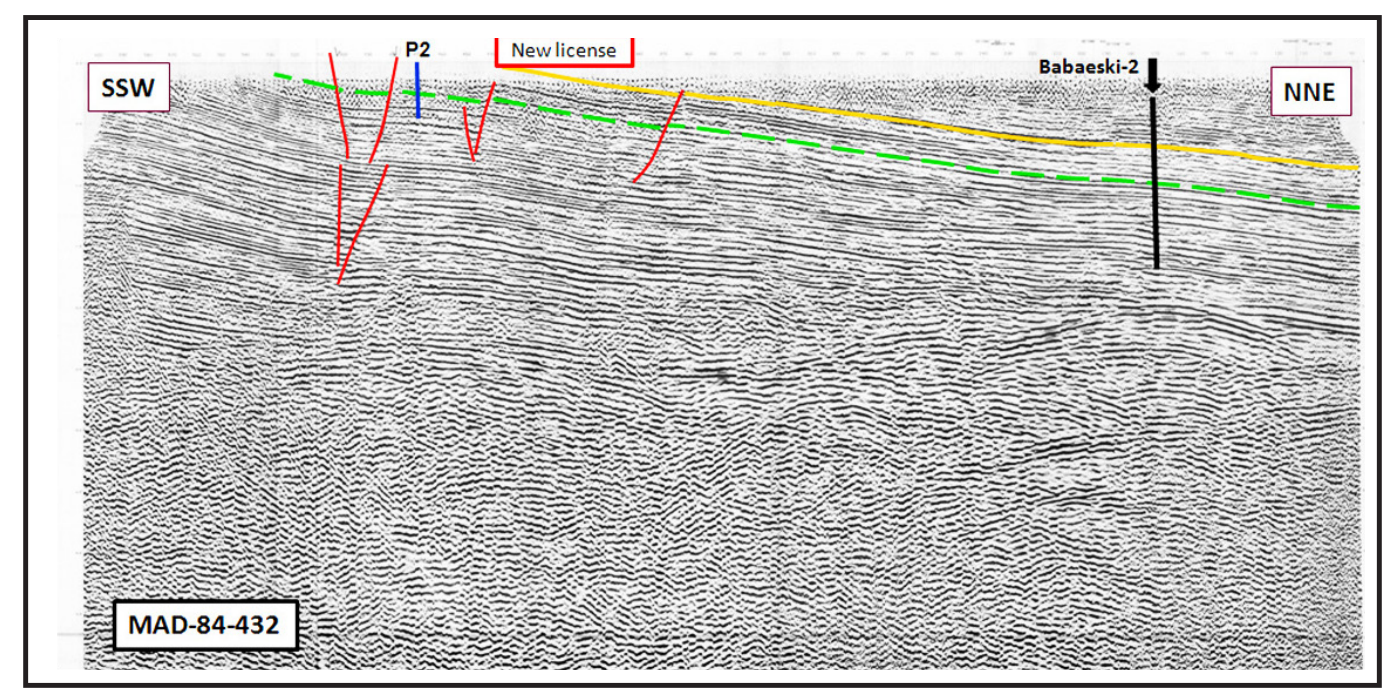

Figure 17 - Seismic section no MAD-84-432. Lignite layers (green) and the base (top of the Danişmen Formation) of Ergene Formation (orange) are marked on the section (for locations see Figures 19 and Figure 5).

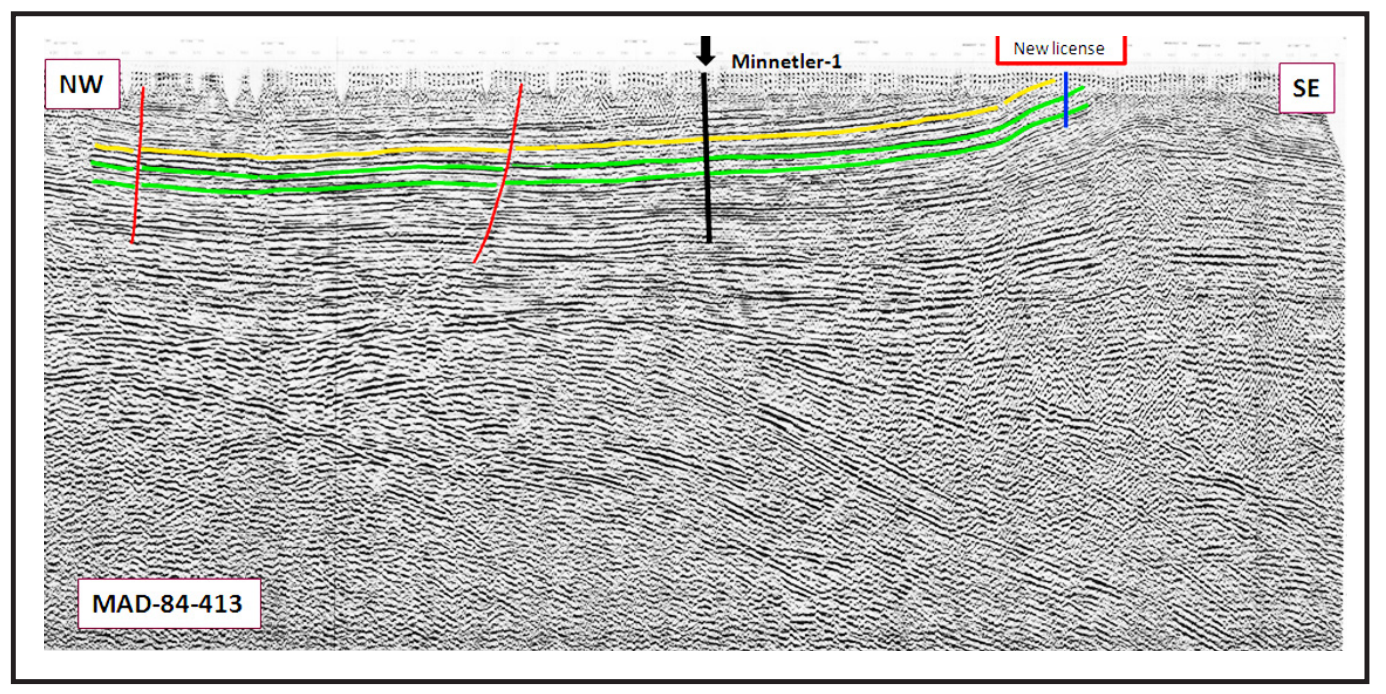

Figure 18 - Seismic section no MAD-84-413. Lignite layers (green) and the base (top of the Danişmen Formation) of Ergene Formation (orange) are marked on the section (for locations see Figures 19 and Figure 5).

cut in areas close to surface and they contain lignite. In the seismic sections red lines represent faults. The locations of TPAO wells (Minnetler 1, Babaeski 2) on the sections are shown with vertical black lines. The locations of wells proposed to be drilled by TKI in 2011 are shown with vertical blue lines.

In figure 16, from Minnetler 1 well to SW and NE directions the reflection that is supposed to represent lignite content is shown to get closer to the surface. $\mathrm{P} 1$ well is projected at $\mathrm{SW}$ of section (for location see Figure 19). This well is in the license area that was owned in the past by TKI. The P3 well shown at NE of figure 16 is within the license area owned by TKI in
2010 (Figure 20). It is suggested that this well should be immediately drilled. In figure 17, the point indicated by $\mathrm{P} 2$ symbol at $\mathrm{SW}$ of section is within the TKİ license area owned in the past years (for location see Figure 19). This well is also preferentially drilled in the area.

\section{Obtaining license and proposed wells}

\subsection{New license areas owned by TKI}

1 - Around Mesutlu 1 well (Figure 13): TKİ was suggested to own license around the Mutlu, Kadıköy, and Kuleli villages in the Karacaoğlan region at north of Babaeski and around Çavuşlu (Figure 12), 
Karacaoğlan, and Oruçlu villages at the northeast (Perinçek et al., 2011). The promising results of maps produced for the Thrace Basin lead to taking these licenses. From these maps the thickness of Ergene Formation is expected to be around $350 \mathrm{~m}$. The same maps also indicate that lignite levels in the Danişmen Formation are achieved at economic depths. In lignite thickness map prepared based on well data total thickness of lignite is expected to be around $10 \mathrm{~m}$.

2 - Around Musulca at south of Süloğlu: TKİ took licenses around the Habiller, Musulca, Arpaç, Küküler, Akardere and Paşayeri villages (south of Süloğlu; Figure 14). In this area, total thickness of Ergene and Kurcasalih formations is nearly 300-400 $\mathrm{m}$. Lignite bands within the Danişmen formation are expected to be cut at economic depths.

\subsection{Wells proposed to be drilled in license areas of} TKI

In the second stage of study conducted for TKİ, a supplementary work was carried out to maintain that reliable data is applied to drilling of wells in present licenses and licenses taken by TKİ in 2010. Before proposed drilling in permit data on TPAO wells around the license areas were taken into account.

Using the prepared maps constructed and other geologic and seismic data, the areas where lignite could be cut at shallow depths are estimated. The data to be achieved in this study contain important tips regarding the depth of lignite levels. As known due to facies changes within the Danişmen Formation lignite levels are discontinuous. Total lignite thickness may change in short distances and become zero.

Northern parts of license areas at S and SE of Pehlivanköy (Figure 19) where TKİ drilled wells in previous years are expected to have lignite levels at economic depths. It is thought that in these areas Danişmen Formation is exposed but Ergene Formation is not present or very thin. Seismic section given in figures 16 and 17 is included to support this opinion. For this area there are limited data to identify facies distribution of Danişmen Formation and the presence of lignite layers. In spite of this, these areas are needed to be tested. If facies is suitable, the number of wells in the license will be increased in north and south directions. In these licenses (Figure 19) wells

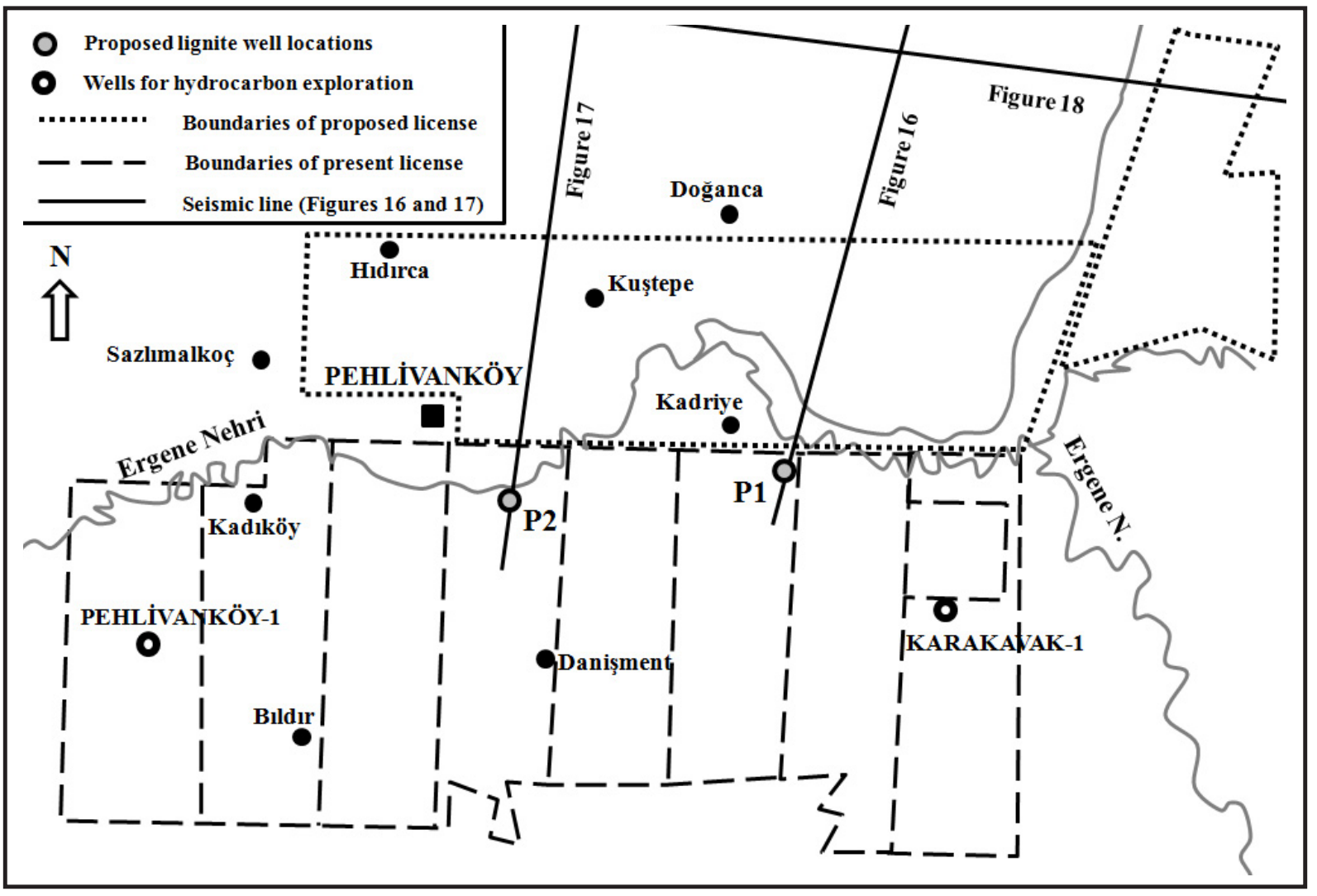

Figure 19 - Locations of wells (P1 and P2) to be drilled in northern parts of license areas of TKI at S and SE of Pehlivanköy. 2 new license areas to be taken around northeast of Pehlivanköy are marked with dashed line. 
P1 (Figure 16) and P2 (Figure 17) are proposed to be drilled. In well P1 lignite level can be penetrated at depth of 100-200 m. Depth of well is proposed to be $400 \mathrm{~m}$. In well P2 lignite level is expected to be encountered between 200-300 m. Depth of this well is suggested as $500 \mathrm{~m}$. It is possible that in wells P1 and P2 (Figure 19) lignite levels can be penetrated much shallower depths.

Wells should be immediately drilled in license areas taken in 2010 around the Karacaoğlan town at north of Babaeski (Figure 20). Locations of proposed wells are shown in Figure 20. On this map P3, P4A, P4-B, P5 and P6 symbols show the proposed well locations. Considering the results from P3 well (Figure 16), locations of these wells may be changed. It is thought that reflection planes, which are believed to represent lignite layers, are intercepted at depth of 200-300 m (Figure 16). In this well, first a thin part of Ergene formation will be cut and then Danişmen Formation will be progressed. It is possible that 2 different lignite levels will be intercepted in the P3 well. The lignite level below could be at depth of 300-400 m. Lignite layers and alternating litologies of Danişmen Formation are expected to have a high slope which results in cutting of a much thicker lignite layer.

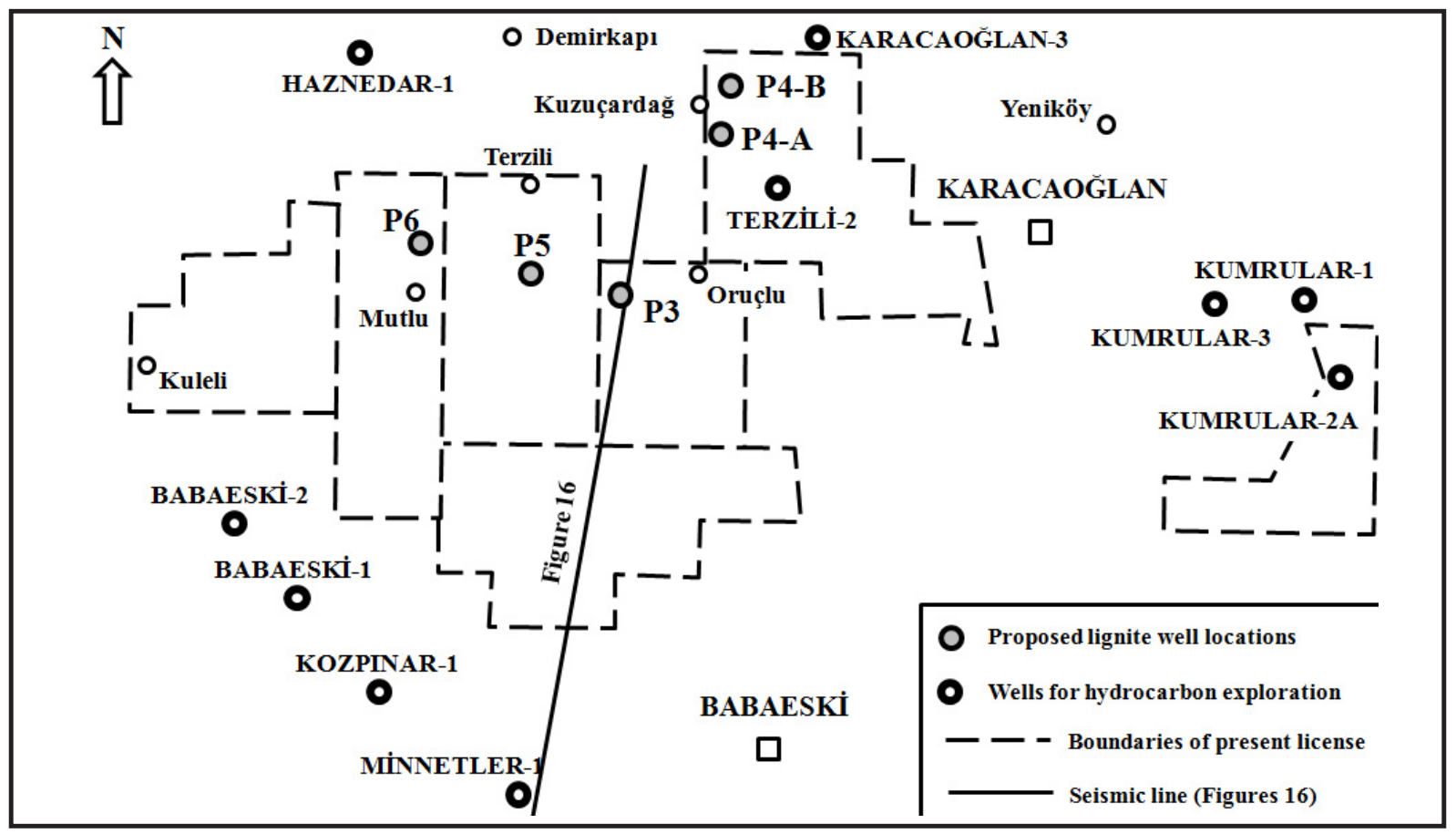

Figure 20 - Map showing the locations of wells to be drilled in license (taken in 2010) areas around Karacaoğlan town at north of Babaeski.

In license areas at south of Umur 1 well north of Hasköy, a number of 8 wells (H1, H2, H3, H4, H5, H6, H6, H7, H8) are proposed (Figure 21). For this area since no seismic data are available it is not possible to suggest a net figure for the depth of lignite layers. However geologic works conducted during the first stage of project indicate that he Ergene Formation is very thin in this area and lignite layers are shallowly seated since Danişmen Formation is eroded and for these reasons present licenses were taken. The locations and arrangement of wells to be drilled in this area may be changed in accordance with results from $\mathrm{H} 1$ well. At north of these licenses in Umur 1 well lignite was cut at depth of $225 \mathrm{~m}$ (Figure 21). In addition, around this well and in the Süloğlu lignite field at north thickness of lignite attains 7-8 $\mathrm{m}$ (Figure 14).

\subsection{Proposed new license areas}

Seismic data yields that lignite levels of the Danişmen Formation will be closer to the surface at east of Pehlivanköy. Therefore new licenses are suggested for this area. As shown from figures 16 and 17 , reflectors which are presumably lignite layers get close to the surface. Just north of TKI license areas around Pehlivanköy at least 2 licenses are suggested. The new license area is marked with red rectangular on the seismic section in figure 16 . 


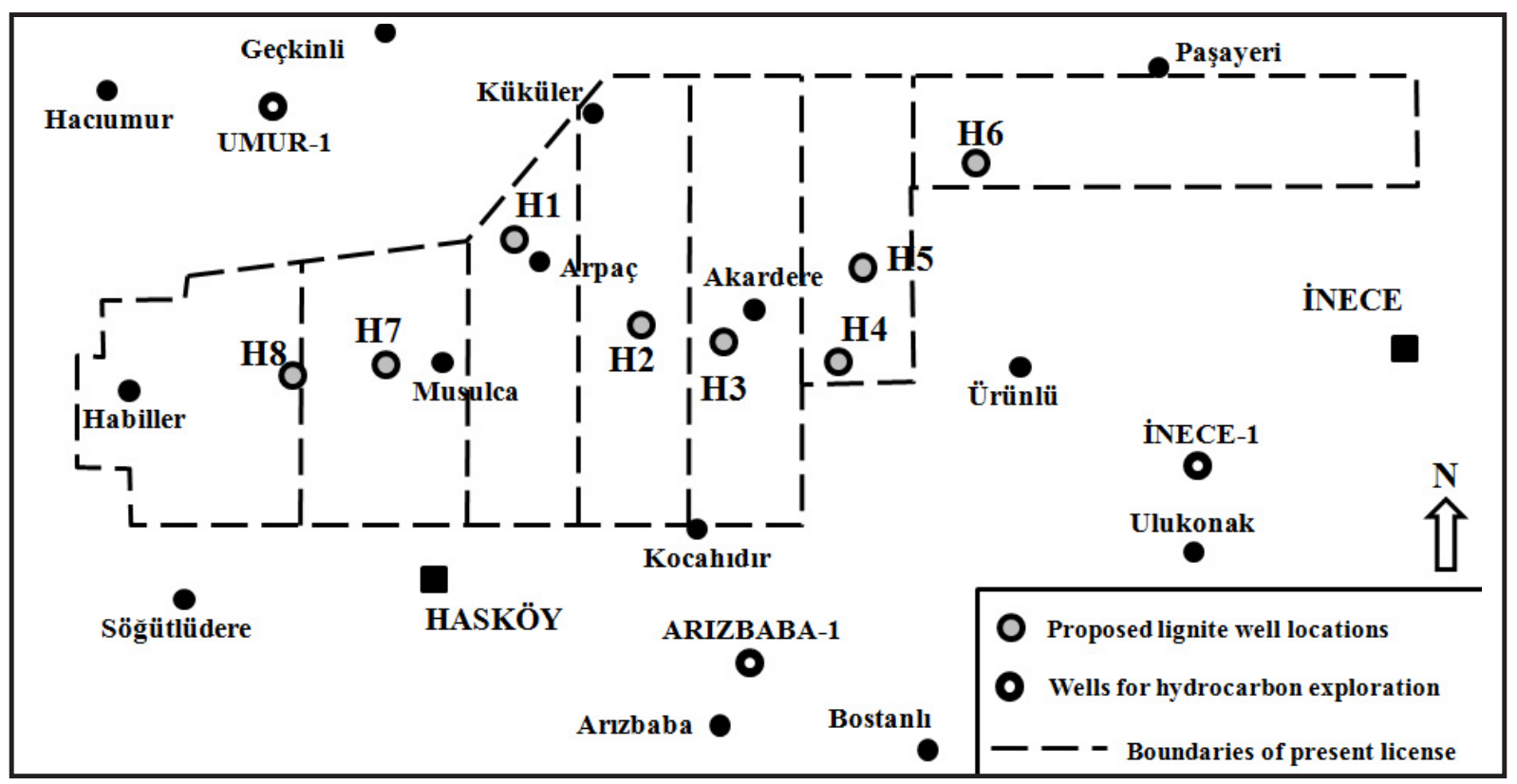

Figure 21 - Proposed wells to be drilled in license areas at north of Hasköy (H1, H2, H3, H4, H5, H6, H7, H8).

Seismic data (Figure 18) indicate that lignitebearing Danişmen Formation at SE of Babaeski area gets close to the surface. It is believed that Ergene Formation will be thin-very thin within the proposed license area. Therefore new licence was suggested for NE of Pehlivanköy area (Figure 19). The proposed license area is marked with red rectangular on the seismic section in figure 18 .

Results of this study show that there are areas suitable for taking new license around PancarköyBabaeski and based on these findings TKI took new licenses in this area.

\section{Results}

Within the concept of project which started in April 2009 studies summarized below were implemented for the whole Thrace basin using TKI, TPAO and MTA well data. In order to reveal lignite potential of Thrace basin maps of regional scale were established. From these maps information was gathered that is useful not only for TKİ but also for TPAO and MTA. It was aimed that results of project will contribute to all relevant governmental organizations (Perinçek $2010 a, b, c)$.

The maps produced from this study are listed below:

1- Osmancik Formation structure map (Figure 6)

2- Danişmen Formation discordance plane "paleotopography" map (Figure 7)
3- Danişmen Formation thickness map (Figure 8): Lignite levels within the Danişmen Formation are generally found in the middle and middle-upper parts of the unit. It is shown in the thickness map that the unit is changes its thickness between of $0-1650$ $\mathrm{m}$. The decrease in thickness is attributed to erosion process following an uplift that is triggered by the Thrace Fault System. In some areas, the Danişmen Formation is completely eroded. As a result, lignite layers within the unit are also eroded. Therefore it is suggested that during the lignite exploration the areas where unit is intensely eroded should be avoided. In areas where the formation is quite thick it is difficult to find lignite layers in the middle part of unit at economic depths. Therefore, in the unit areas with thickness exceeding $1000 \mathrm{~m}$ are risky which should be kept away.

4- For lignite levels within the Danişmen Formation 2 total thickness maps were prepared (Figures 12 and 13). First using the TPAO well data total lignite thickness map was prepared (Figure 12) then a second map was produced using well data from MTA and TKI. Data in total lignite thickness map based on TPAO data may contain some mistakes since TPAO is not an organization specialized in lignite. Therefore, lignite thickness map produced by TPAO data (Figure 12) was reviewed using geological data from the region and combined with total lignite thickness map established by TKİ-MTA data. Thus a total lignite thickness map was obtained for the whole Thrace region (Figure 13). This study revealed that lignite distribution in 
the Thrace region was partly developed under facies control and Thrace Fault System (Perinçek, 1987; 1991). Was controlling thickness of the lignite These new findings are important for the geology of Thrace region and may contribute to lignite and oil exploration works in the region.

5- In order to examine thickness of Ergene Formation within the basin, thickness map of this formation was prepared throughout the Thrace basin (Figure 15). It is shown on this map that the unit changes between 0-1250 m. Based on this map, in areas where thickness of Ergene Formation exceeds 400 m, it is difficult to find lignite layers of the Danişmen Formation at economic depths. Therefore areas where thickness of unit exceeds $400 \mathrm{~m}$ should be avoided.

6- In the Thrace region stratigraphic correlations were made considering the data from wells drilled by MTA and TKİ. Data from these correlations provided understanding the lateral and vertical facies change of lignite. These correlations were evaluated together with other maps and issues and as a result new licenses were suggested to be taken in areas of high lignite potential (Perinçek et al., 2011). Results of these correlations and similar works are scope of a different paper.

7- In areas with licenses taken by TKI in 2010 and previous years, locations of wells to be drilled in the coming years were determined. These wells will be drilled in a sequence. During the drilling stage, results of previous well will be taken into account and if necessary the order of drilling will be changed. When programming the drilling of wells around Pehlivanköy and Karacaoğlan areas (Figures 19 and 20) results of subsurface maps were used and there are geologic and seismic controls. However, locations of wells in areas at north of Hasköy (Figure 21) wells locations are based solely on geologic data from maps.

8- In the second stage of project, following the completion of maps based on geologic data and seismic assessment, based on the results acquired TKI obtained new licenses (Perinçek et al., 2011).

9- Using the results of this study that was conducted for the whole Thrace basin a new exploration strategy was established. In this respect, new licenses are suggested near by uplifted areas of the Thrace Fault System. The areas where the Danişmen Formation is partly eroded around the paleo-heights and the overlying Ergene Formation is quite thin are selected as the target. This new strategy is one of the important results of this study.

The maps and reports that prepared for the Thrace basin were submitted to TKI in 2010. As a result of findings from this report, a new exploration strategy was established to determine and own new license areas (Perinçek et al., 2011). When making such decisions, subsurface and surface geologic data were evaluated in conjunction with seismic data and exceptionally different method was pursued. Well locations were determined following the assessment of all data.

\section{Studies planned in the coming years}

1- If the results of chemical analysis of samples from wells drilled by TKI and MTA are provided for the whole Thrace basin, calorie distribution maps are suggested. Numerous numbers of analyses is required for successful results from these maps and therefore reliable results cannot be achieved with limited data. These maps which will be established with chemical analyses may also provide information on facies characteristics of the Danişmen Formation.

2- Facies map of Danişmen Formation is another attempt to accurately reveal the lignite potential of Thrace basin. It is possible to examine lateral and vertical facies changes with well correlations. In order to see the vertical facies in map dimension (third dimension) facies maps should be constructed. Underground geology data of TPAO are important data set that should be used during preparation of facies maps. These data are well logs and composite well logs. Facies maps of Danişmen Formation can be made providing these data from TPAO. Geology maps are another data set for these maps. The facies maps should be supported with field works. When making maps sections in some exposures should be visited and surface and subsurface data must be combined. In the long term lignite potential of Thrace basin is thought to be transformed to gas by burning underground. In this case, rather than depth of lignite levels, lateral changes in association with facies distribution come into prominence. In order to minimize the drilling costs facies works are crucially important. Facies study is indispensable for the Thrace basin which requires a longsuffering work.

3- Thickness and structure maps produced so far should be continuously revised with data from new wells drilled by TKİ, MTA and TPAO and then wells for lignite production should be drilled on 
reliable points. Data on wells to be drilled by various organizations must be evaluated simultaneously with other proposed works. Thus a complementary system will be established and works will be carried out in more coordinated way. Data of wells to be drilled in the Thrace basin by TKI and other relevant organizations will provide a great support in construction of facies maps. During the generation of facies maps, data on these wells will be evaluated and taking the results of each stage into consideration if necessary facies maps will be updated. Thus new wells to be drilled will be directed to areas of high expectation.

\section{Acknowledgements}

Subsurface geology data were provided by TKI, MTA and TPAO. Without well data and other information given by TPAO to TKİ organization this study would not be possible. TKI and ÇOMÜ team thank MTA and TPAO organizations and staff for providing access to data set. Special thanks go to Ayhan Kösebalaban, İsmail Ergüder and Yaşar Ünal who supported the project and made data flow possible.

Received: 28.06.2014

Accepted: 01.11.2014

Published: June 2015

\section{References}

Akartuna, M. 1968. Armutlu yarımadasının jeolojisi. Istanbul Üniversitesi Fen Fakültesi Monografiler 20, 105 s.

Alişan, C. 1985. Trakya "I" Bölgesi'nde Umurca-1, Kaynarca-1, Delen-1 kuyularında kesilen formasyonların palinostratigrafisi ve çökelme ortamlarının değerlendirilmesi. TPAO. Araştırma Grubu Rapor No: 386, 60 s. Ankara (unpublished)

Atalık, E. 1992. Depositional systems of the Osmanc1k formation in the Thrace Basin. Doktora Tezi, Orta Doğu Teknik Üniversitesi, 343 s. Ankara (unpublished).

Barka, A. 1981. Seismo-tectonic aspect of the North Anatolian Fault Zone: Ph.D thesis, University of Bristol, Bristol England, 333 p

Barka, A., Hancock, P. 1984. Neotectonic deformation patterns in the convex-northwards arc of the North Anatolian Fault Zone. In: Dixon, J.E., Robertson, A.H.F. (Eds), The Geological Evolution of the Eastern Mediterranean Region. Geol. Soc. London, pp. 763-773.

Batı, Z., Erk, S., Akça, N. 1993. Trakya Havzası Tersiyer Birimleri'nin Palinomorf, Foraminifer ve Nannoplankton Biyostratigrafisi. TPAO Araştırma Grubu Rapor No: 1947, 92 s. Ankara (unpublished).
Bat1, Z., Alişan, C., Ediger, V.Ş., Teymur, S., Akça, N., Sancay, H., Ertuğ, K., Kirici, S., Erenler, M., Aköz, Ö. 2002. Kuzey Trakya Havzası'nın Palinomorf, Foraminifer ve Nannoplankton Biyostratigrafisi, Türkiye Stratigrafi Komitesi Çalıștayı (Trakya Bölgesi’nin Litostratigrafi Adlamalarl) Özleri, s. 14.

Burke, W. F., Uğurtaş, G. 1974. Seismic interpretation of Thrace Basin, in H. Okay and E. Dileköz, eds., Proceeding of second petroleum congress of Turkey: Association of Turkish Petroleum Geologists, 227-248

Bürkan, K. 1992 1:50 000 ölçekli Trakya F29 c ve d paftaları jeoloji haritası, Türkiye Petrolleri Anonim Ortaklı̆̆ Arama Grubu Arşivi.

Çağlayan, M.A., Yurtsever, A. 1998. Burgaz-A3, Edirne-B2 ve B3; Burgaz-A4 ve Kırklareli-B4; Kırklareli-B5 ve B6; Kırklareli-C6 paftaları Maden Tetkik ve Arama Genel Müdürlüğü, 1:100 000 ölçekli açınsama nitelikli Türkiye jeoloji haritaları, No: $20,21,22,23$.

Doust, H., Arıkan, Y. 1974. The geology of the Thrace Basin, Türkiye İkinci Petrol Kongresi Tebliğleri Kitabl, s. 119-136.

Duman, T.M., Keçer, M., Ateş, Ş., Emre, Ö., Gedik, İ., Karakaya, F., Durmaz, S., Olgun, Ş., Şahin, H., Gökmenoğlu, O. 2004. İstanbul metropolü batısındaki (Küçükçekmece Silivri-Çatalca yöresi) kentsel gelişme alanlarının yer bilim verileri, Maden Tetkik ve Arama Genel Müdürlüğü Özel Yayın Serisi- 3.

Ediger, V. Ş. 1982. Kuleli Babaeski sırtının (KB Trakya) Paleo-ortamsal incelemesi ve Kuzey Trakya havzasının hidrokarbon potansiyelinin değerlendirilmesinde yeni yaklaşım: Türkiye Petrolleri Anonim Ortaklığı Rapor No: 1995, 194 s. Ankara (unpublished).

Ediger, V. Ş. 1988. Biga Yarımadası'ndaki kömürlü birimlerden alınan örneklerin palinolojik analizi, Türkiye Petrolleri Anonim Ortakliğ Araştırma Merkezi Grubu Rapor No: 809, Ankara (unpublished)

Ediger, V.Ş., Alişan, C. 1989. Tertiary fungal and algal palynomorph biostratigraphy of the northern Thrace basin, Turkey. Review of Palaeobotany and Palynology 58, 139-161.

Fourquin, C. 1979. L'Anatolie du nord-ouest, marge méridionale du continent Européen, historie paléogéographique, tectonique et magmatique durant le Secondaire et le Tertiaire: Bulletin de la Société Géologique de France, 17, 1059-1070.

Gerhard, J.E., Alişan, C. 1987. Palynostratigraphy, paleoecology, and visual organic geochemistry Turgutbey-2, Değirmencik-3 and Pancarköy-1, Thrace Basin, Turkey. Türkiye Petrolleri Anonim Ortakliğ A Araştırma Merkezi Grubu Rapor No: 983, 33 s. Ankara (unpublished). 
Gökçen, N. 1971. Güneydoğu Trakya'nın Paleojen stratigrafisinde ostracod'lar açısından yeni görüşler. Türkiye 1. Petrol Kongresi Bildirileri Kitabı, 81-85.

Görür, N., Okay, A.I. 1996. Fore-arc origin of the Thrace basin, northwest Turkey. Geologische Rundschau, $85,662-668$.

İmik, M. 1988. Kırklareli-C2-3 Paftas1 ve İzahnamesi. Maden Tetkik ve Arama Genel Müdürlüğü 1:100 000 ölçekli Türkiye Jeoloji Haritaları, , $10 \mathrm{~s}$.

Kara, H., Tuncal1, E., Narin, R., Gürsoy, B., Dümenci, S. 1996. Trakya Tersiyer kömür havzas1 raporu. Maden Tetkik ve Arama Genel Müdürlüğ̈̈ Rapor No: 9974, Ankara, (unpublished).

Kasar, S., Bürkan, K., Siyako M., Demir, O. 1983. Tekirdağ- Şarköy-Keşan-Enez bölgesinin jeolojisi ve hidrokarbon olanakları. Türkiye Petrolleri Anonim Ortaklı̆̆ Arama Grubu Rapor No: 1771, 71 s. Ankara (unpublished).

Kasar, S., Eren, A. 1986. Kırklareli-Saray-Kıyı̈öy bölgesinin jeolojisi. Türkiye Petrolleri Anonim Ortakliğı Arama Grubu Rapor No: 2208, 45 s. Ankara (unpublished)

Kasar, S. 1987. Edirne-Kırklareli-Saray (Kuzey Trakya) bölgesinin jeolojisi. Türkiye 7. Petrol Kongresi Tebliğleri Kitabı, 281-291.

Keskin, C. 1974. Kuzey Trakya Havzası'nın Stratigrafisi. Türkiye İkinci Petrol Kongresi Tebliğleri Kitabl, $137-163$.

Ketin, İ. 1957. Kuzey Anadolu Deprem Fay1. Istanbul Teknik Üniversitesi Dergisi, İstanbul Türkiye, no. $15,49-52$

Ketin, İ. 1976. San Andreas ve Kuzey Anadolu fayları arasında bir karşılaştırma: Türkiye Jeoloji Kurumu Bülteni, 19, 149-154

Kopp, K.O., Pavoni, N., Schindler, C. 1969. Geologie Thrakiens IV: Das Ergene-Becken. Beih zum Geol. Jahrb., Heft 76, 136 s., Hannover.

Lebküchner, R.F., 1974. Orta Trakya Oligosen'nin jeolojisi hakkında. Maden Tetkik ve Arama Enstitüsü Dergisi 83, 1-29, Ankara.

N.V. Turkse Shell. 1969. AR/NTS/837, 838 ve 839 hak sira no'lu arama ruhsatlarına ait terk raporu. Türkiye Petrolleri Anonim Ortaklığı Arama Grubu Rapor No: 1468. Ankara (unpublished).

Öztunal1, Ö., Üşümezsoy, Ş. 1979. Istranca Masifi'nin "Çekirdek" kayaçları ve petrojenetik evrimleri. Türkiye Jeoloji Kurumu-İstanbul Üniversitesi Yerbilimleri Fakültesi, Altınlı Sempozyumu, 37-44.

Perinçek, D. 1987. Trakya Havzası Renç Fay Zonunun Sismik Özellikleri. Türkiye 7. Petrol Kongresi Bildirileri, 11-20

Perinçek, D. 1991, Possible strand of the North Anatolian Fault in the Thrace Basin, Turkey - An Interpretation. AAPG Bulletin 75, $241-257$.
Perinçek, D. 2006. Marmara - Trakya havzalarının Yapısal Evrimi ve Fayların Zamansal Gelişimi. Çanakkale Onsekiz Mart Üniversitesi, Genç Jeo (Jeoloji Öğrenci Topluluğu) Çanakkale, 27-38

Perinçek, D., Karslığlu, Ö. 2007. Çanakkale Boğazı'nın oluşumu ve Kuvaterner yaşlı birimlerin dağılımında fayların rolü. 60. Türkiye Jeoloji Kurultayı Bildiri Özetleri, 16-22 Nisan, Ankara, 478-479.

Perinçek, D. 2010a. Trakya Havzası'nın Linyit İmkanları TKI Rapor, Ocak 2010, 55 s. Ankara (unpublished).

Perinçek, D. 2010b. Trakya Havzası'nın Linyit İmkanları TKI Rapor, Mart 2010, 37 s. Ankara (unpublished).

Perinçek, D. 2010c. Trakya Havzası'nın Linyit İmkanları TKI Final Rapor, Aralık 2010, 51 s. Ankara (unpublished).

Perinçek, D., Ataş, N., Erensoy, E., Karatut, Ş. Kösebalaban, A., Ergüder İ., Ünal., Y. 2011. Trakya Havzası'nın linyit potansiyeli ve bunu kontrol eden jeolojik faktörler. 64. Türkiye Jeoloji Kurultayl Bildiri Özetleri, 16-25-29 Nisan 2011, Ankara, 93-94

Saner, S. 1985. Saros Körfezi dolayının çökelme istifleri ve tektonik yerleşimi, Kuzeydoğu Ege Denizi, Türkiye. Türkiye Jeoloji Kurumu Bülteni, 28, 1-10.

Saraç, G. 1987. Kuzey Trakya bölgesinde Edirne-KırklareliSaray-Çorlu-Uzunköprü Derekebir yörelerinin memeli paleo-faunas1, Ankara Univ., Fen Bil. Enst., Jeo. Müh. Anabilim Dalı, Yük. Lisans Tezi. Ankara (unpublished).

Siyako, M. 2005. Trakya ve yakın çevresinin Tersiyer stratigrafisi. Türkiye Petrolleri Anonim Ortakliğg Arama Grubu Rapor No: 4608, 104 s. Ankara (unpublished)

Siyako, M. 2006a. Trakya Havzası'nın linyitli kumtaşları, Maden Tetkik ve Arama Genel Müdürlüğü Dergisi, $132,63-73$.

Siyako, M. 2006b. Trakya Bölgesi Litostratigrafi Birimleri (Tersiyer Bölümü). Stratigrafi Komitesi, Litostratigrafi Birimleri Serisi-2. Maden Tetkik ve Arama Genel Müdürlüğü yayını. $70 \mathrm{~s}$

Siyako, M., Kasar, S. 1985. Edirne-Lalapaşa-Kırklareli bölgesinin jeolojisi. Türkiye Petrolleri Anonim Ortaklığ Arama Grubu Rapor No: 2062, 78 s. Ankara (unpublished)

Siyako, M., Bürkan, K., Okay, A.I. 1989. Biga ve Gelibolu yarımadalarının Tersiyer jeolojisi ve hidrokarbon olanakları. Türkiye Petrol Jeologları Derneği Bülteni, 1, 183-199.

Sümengen, M., Terlemez, İ. 1991. Güneybatı Trakya yöresi Eosen çökellerinin stratigrafisi. Maden Tetkik Arama Dergisi, 113, 17-30.

Sütçü, E., Paker, S., Nurlu, Y., Kumtepe, P., Cengiz, T. 2009. Tekirdağ-Malkara havzasında CBS yöntemleriyle potansiyel kömür sahalarının belirlenmesine yönelik iki değişkenli istatistiksel yaklaşım. TMMOB Coğrafi Bilgi Sistemleri Kongresi, 02-06 Kasım 2009, İzmir, 8 s. 
Şengüler, İ. 2008. Trakya Havzası Kömür Aramaları Projesi Raporu (2005-2006-2007 Y1l Sondajları), Maden Tetkik Arama Genel Müdürlüğ̈̈ Rapor No: 11069, Ankara, (unpublished).

Şengüler, İ. 2013. Ergene (Trakya) Havzası'nın jeolojisi ve kömür potansiyeli. Maden Tetkik Arama Genel Müdürlüğ̈̈ Doğal Kaynaklar ve Ekonomi Bülteni Say1 16, 109-114

Şengüler, İ., Toprak, S., Kara, H., Öner, A., Tuncalı, E., Kır, N. 2000. Güney Trakya Bölgesindeki Kömürlerin Petrografik İncelemesi ve Ortamsal Yorumu. Türkiye 12. Kömür Kongresi Bildiriler Kitabl, Karadeniz Ereğlisi, Zonguldak. 173-180.

Şengüler, İ., Akman, Ü., Taka, M., Dümenci, S., Kalkan, İ., Kır, N., Sulu, K. 2003. Güney Marmara Neojen Havzalarının Kömür Potansiyeli. 56. Türkiye Jeoloji Kurultayı Bildiri Özleri Kitabı, Ankara, 212-213,

Şentürk, K. Sümengen, M., Terlemez, İ., Karaköse, C. 1998a. Çanakkale- D3 Paftası Maden Tetkik ve Arama Genel Müdürlüğü, 1:100 000 ölçekli açınsama nitelikli Türkiye jeoloji haritaları, 63 .

Şentürk, K. Sümengen, M., Terlemez, İ., Karaköse, C. 1998b. Çanakkale D4 Paftası Maden Tetkik ve Arama Genel Müdürlüğü, 1:100 000 ölçekli açınsama nitelikli Türkiye jeoloji haritaları, 64 .

Taner, F., Çağatay, A. 1983. Istranca masifindeki maden yataklarının jeolojisi ve minerolojisi. Türkiye Jeoloji Kurumu Bülteni, Ankara, Türkiye, v.26, $31-40$

Temel, R.Ö. ve Çiftçi, N.B. 2002. Gelibolu Yarımadası, Gökçeada ve Bozcaada Tersiyer çökellerinin stratigrafisi ve ortamsal özellikleri. Türkiye Petrol Jeologları Derneği Bülteni 14, 17-40.

Turgut, S., Siyako, M., Dilki, A. 1983. Trakya Havzası'nın jeolojisi ve hidrokarbon olanakları. Türkiye Jeoloji Kongresi Bülteni, 4, 35-46.
Turgut, S., Türkaslan, M., Perinçek, D. 1991. Evolution of the Thrace sedimentary basinand its hydrocarbon prospectivity. Spencer AM (ed) Generation, accumulation, and production of Europe's hydrocarbons. Special Publication of Eurapean Association of Petroleum Geoscientists, 1, 415-437.

Turgut, S., Eseller, G. 2000. Sequence stratigraphy, tectonics and depositional history in Eastern Thrace Basin, NW Turkey. Marine and Petroleum Geology, 17, 61-100.

Türkecan, A., Yurtsever A. 2002. İstanbul Paftas1, 1: 500 000 ölçekli Türkiye Jeoloji Haritası Serisi. Maden Tetkik ve Arama Genel Müdürlüğü, Ankara.

Umut, M, İmik, M., Kurt, Z., Özcan, İ., Sarıkaya H., Saraç, G. 1983. Tekirdağ, Silivri (İstanbul), Pınarhisar alanının jeolojisi. Maden Tetkik ve Arama Genel Müdürlüğ̈̈ Rapor No: 7349. Ankara (unpublished).

Umut, M. 1988a. Kırklareli-C5 Paftas1 ve İzahnamesi, 1:100 000 ölçekli Türkiye Jeoloji Haritaları, Maden Tetkik ve Arama Genel Müdürlügüu, Ankara $10 \mathrm{~s}$.

Umut, M. 1988b. Kırklareli-C4 Paftas1 ve İzahnamesi, 1:100 000 ölçekli Türkiye Jeoloji Haritaları, Maden Tetkik ve Arama Genel Müdürlügüu, Ankara $6 \mathrm{~s}$.

Umut, M, İmik, M., Kurt, Z., Özcan, İ., Ateş, M., Karabıyıkoğlu M., Saraç, G. 1984. Edirne İli-Kırklareli İli-Lüleburgaz (Kırklareli İli)Uzunköprü (Edirne İli) civarının jeolojisi.. Maden Tetkik ve Arama Genel Müdürlüğü Rapor No: 7604, 42 s. Ankara (unpublished).

Üşümezsoy, Ş. 1982. Igneous and metamorphic geology and mineralization of Istranca region (Geotectonic setting and mineralization of the Istranca masif). İstanbul University Earth Sciences Review, v.3, no. $1-2,227-294$

Ünal, O. T. 1967. Trakya jeolojisi ve petrol imkanları. Türkiye Petrolleri Anonim Ortaklı̆̆ Arama Grubu Rapor No: 391, 80 s. Ankara (unpublished) 
